\title{
Padrões musicais do samba-enredo na era do Sambódromo
}

\section{Yuri Prado}

Resumo: Através da apresentação de algumas das estruturas musicais mais recorrentes no samba-enredo dos últimos trinta anos, o presente artigo procura estabelecer uma terminologia para tais fenômenos e fazer uma reflexão sobre o processo de padronização sofrido pelo samba-enredo, tendo como base o conceito de mudança musical sugerido por John Blacking.

Abstract: Through presentation of some of the most recurring music structures of samba-enredo in the last thirty years, this article intends to establish a terminology for such phenomena and to reflect on the patterning process suffered by the genre, based on the concept of musical change suggested by John Blacking.

\section{Introdução}

Embora a maioria de nós consiga perceber mudanças estilísticas de um determinado gênero musical quando o observamos em uma perspectiva histórica, poucos autores souberam definir o conceito de mudança musical de maneira tão precisa quanto John Blacking em seu artigo Some Problems of Theory and Method in the Study of Musical Change (1977). De acordo com Blacking,

para ser qualificado como uma mudança musical, o fenômeno descrito deve constituir uma mudança na estrutura do sistema musical, e não simplesmente uma mudança dentro das fronteiras do sistema. Isso não significa que as mudanças musicais podem ser estudadas somente no nível macro, total. Ao contrário, uma atenção 
especial às constantes micro-variações é essencial, visto que elas podem revelar os germes da mudança (BLACKING, 1977: 17).

Blacking defende que "nenhum estudo de mudanças musicais é possível sem uma perspectiva diacrônical" (1977, p. 18, grifo meu). Assim, somente através do estudo de determinada manifestação musical em um período de tempo considerável podem ser identificados não somente os momentos de mudança, mas também os períodos de latência, em que há mudanças graduais em direção à mudança (1977, p. 18-19).

Com relação ao samba-enredo, objeto de estudo do presente artigo, o fato de este ser um gênero musical privilegiado no que diz respeito ao registro fonográfico, na medida em que são lançados anualmente discos com as obras compostas para cada carnaval, permite que se possa observar suas transformações em uma perspectiva diacrônica de maneira bastante nítida. Portanto, a partir da escuta e análise de fonogramas dos discos oficiais, e tendo como pano de fundo os conceitos discutidos por John Blacking, pretendo demonstrar o surgimento, permanência e desuso de certos padrões musicais em sambas-enredo do período contemporâneo das escolas de samba do Rio de Janeiro, cujo marco simbólico é a construção, em 1984, do Sambódromo na Avenida Marquês de Sapucaí.

\footnotetext{
1 Blacking crê ainda que é igualmente importante a realização de uma perspective sincrônica, "na qual as atividades e fronteiras da comunidade musical são investigadas, a vim de verificar as normas dos praticantes e determinar quais aspectos da ação são vistos como musicais" (1977, p. 8). Desta forma, o pesquisador deve lidar com "as necessidades conflitantes de estudar um sistema musical tanto intensivamente em seu contexto social quanto nos seus vários estágios de evolução" (1977, p. 19). Embora o foco deste artigo seja a realização de um panorama histórico, depoimentos de compositores de samba-enredo serão integrados à discussão dos fenômenos apresentados, na tentativa de apreendermos a visão dos personagens atuantes no universo das escolas de samba.
} 


\section{O samba-enredo como música de consumo}

Se tomarmos como referência o ano de 1932, quando ocorreu o primeiro desfile das escolas de samba do Rio de Janeiro, veremos que foram necessários quase quarenta anos para que a música dessas agremiações passasse a ser registrada em disco de maneira contínua. Em 1968, foram lançados dois LPs que reuniam os sambas-enredo apresentados naquele carnaval: As dez grandes escolas cantam para a posteridade seus sambas-enredo de 1968, produzido pelo Museu da Imagem e do Som (MIS); e Festival de Samba - Gravado ao Vivo, pela gravadora Discnews. Enquanto o primeiro tinha um propósito documental, o segundo daria início à prática de gravação e lançamento de discos anuais de samba-enredo que perdura até hoje².

A divulgação dos sambas-enredo alguns meses antes do carnaval trouxe mudanças importantes na maneira com que a música passou a ser assimilada no desfile. De acordo com Ana Maria Rodrigues,

até o início da transformação do samba-enredo em "sambacomercial", na década de 70 , os compositores não se haviam ainda preocupado com o fato de o público assistente cantar ou não o samba da escola, uma vez que o samba era feito ludicamente, para diversão dos integrantes do desfile. Para um bom desempenho na avenida, o que era uma questão de honra, o samba se ocupava em contar mais detalhadamente o enredo. Isso, aliado à preocupação em situar o tema nos feitos históricos, tornava os sambas difíceis de serem apreendidos em pouco tempo. Como ainda não havia grande divulgação, somente os assistentes que tivessem tido um contato anterior com a música cantavam junto (Rodrigues, 1984, p. 65).

\footnotetext{
2 Em 1970, a Associação das Escolas de Samba do Estado da Guanabara (AESEG), em parceria com a gravadora Caravelle, se encarregaria da produção dos discos oficiais de samba-enredo, o que não impediu a produção, até o ano de 1971, da série Festival de Samba, pela gravadora Relevo. De acordo com Carla Maria de Oliveira Vizeu, somente em 1972 a AESEG estabeleceu um contrato com a Top Tape, pelo qual "o samba escolhido pela escola só poderia ser gravado no disco da Associação" (Vizeu, 2004: 71). Entretanto, encontramos ainda um último registro de sambas-enredo feito pela Relevo nesse mesmo ano, intitulado Desfile de sambas (RV-209).
} 
Assim, pela primeira vez na história, o público que não frequentava os ensaios das escolas podia assistir ao desfile sabendo cantar todos os sambas. Além disso, o samba-enredo despertava cada vez mais o interesse das rádios:

Os sambas-enredo de maior sucesso passaram a ser os de mais fácil memorização. O grande público, submetido ao constante assédio das emissoras de rádio, tornava-se juiz da excelência dos sambas já divulgados antes do carnaval. Consagrava-se um processo circular, pelo qual o melhor samba-enredo era na verdade o mais divulgado, e vice-versa (Augras, 1998; p. 85).

Nesse processo de massificação do samba-enredo, Festa para um rei negro, samba do Salgueiro de 1971 composto por Zuzuca, teve papel de destaque. Sérgio Cabral nos dá uma ideia do sucesso desse samba:

Descoberto pelos veículos de comunicação bem antes do carnaval, a gravação do samba Festa para um rei negro passou a ser executada pelas emissoras de rádio e o seu autor foi convocado para cantá-lo na Discoteca do Chacrinha, o programa mais popular da televisão brasileira. Dos bailes pré-carnavalescos ao carnaval propriamente dito, passando pela banda de Ipanema e por outras bandas de rua, o samba do Salgueiro foi a música mais cantada no verão carioca de 1971 (Cabral, 1996, p. 196-197).

As relações entre música popular e indústria cultural foram objeto de análise do filósofo alemão Theodor Adorno. Para ele,

os padrões musicais da música popular foram originalmente desenvolvidos num processo competitivo. Quando uma determinada canção alcançava um grande sucesso, centenas de outras apareciam, imitando aquela que obtivera êxito. Os hits de maior sucesso, tipos e "proporções" entre elementos eram imitados, tendo o processo culminado na cristalização de standards (Adorno, 1986, p. 121). 
Obviamente, essa visão apresenta problemas: a atribuição da existência de padrões musicais na música popular unicamente à procura pelo sucesso negligencia o fato de as fórmulas poderem ser resíduos de uma tradição oral que permeou o processo de sedimentação de muitos dos gêneros populares. Entretanto, ela pode ser útil para o entendimento de um contexto bem localizado no tempo e nitidamente inserido na dinâmica da indústria cultural, como é o caso do samba-enredo do período abordado.

A necessidade de as escolas desfilarem com sambas de fácil canto e memorização fez com que os compositores buscassem estruturas musicais que melhor servissem a esse propósito. Entre essas estruturas, destaco uma bastante utilizada durante toda a década de 1970 para a construção de refrões. Sua divisão pode ser feita da seguinte maneira:

1) apresentação de uma pequena célula rítmico-melódica (proposição);

2) repetição rítmica dessa célula, geralmente com adaptações de altura decorrentes da mudança harmônica;

3) frase conclusiva de caráter contrastante (resolução).

Os sambas cujos exertos são apresentados a seguir ilustram essa prática (Figuras 1 a 6 ):

Figura 1 - Refrão de Réquiem por um sambista, Imperatriz Leopoldinense, 1974 :

"Réquiem por um sambista", Imperatriz Leopoldinense, 1974 (Cosme / Damião / Guga)

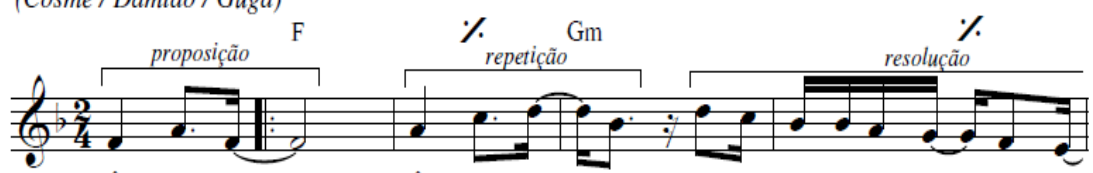

Ô - lê - lê,_ Ô - lá - lá,

A - té ho-je te - mos_sau - da

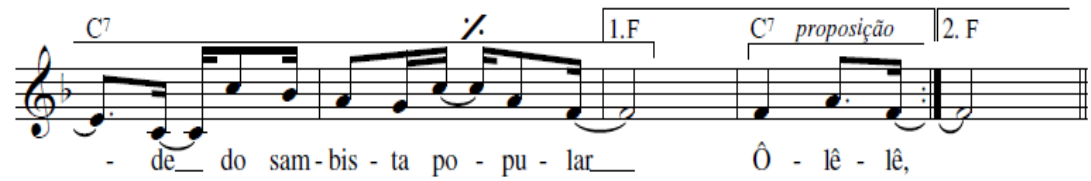


Figura 2 - Refrão de "Personagens marcantes do carnaval carioca", Em cima da hora, 1975

"Personagens marcantes do carnaval carioca", Em cima da hora, 1975

(Cigarra)

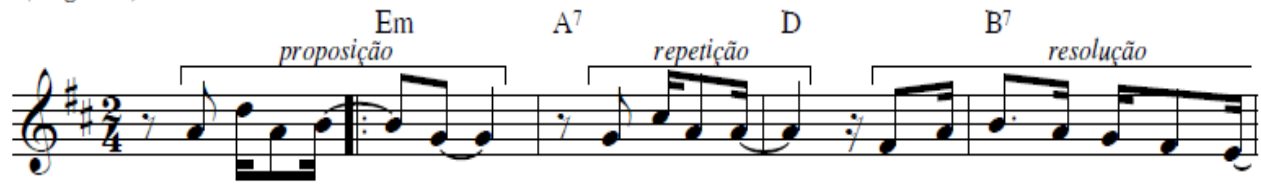

0 - lê, 0 - lê

O - lê, 0 - lá

So - cie - da - des, mi - nha gen

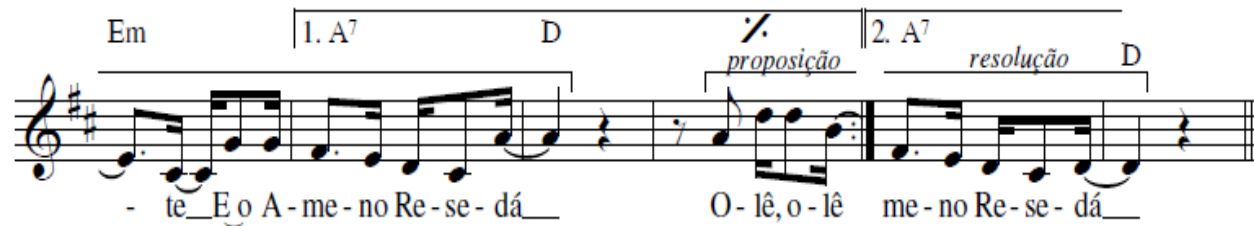

Figura 3 - Refrão de "Mãe menininha do Gantois", Mocidade Independente, 1976

"Mãe menininha do Gantois", Mocidade Indepedente, 1976

(Toco / Djalma Crill)

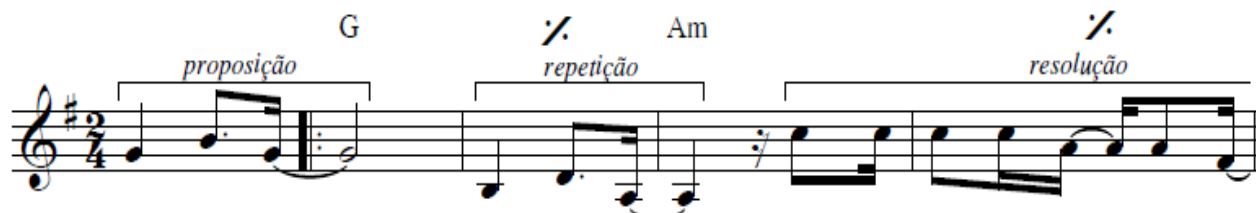

A - re - rê,__ a - re - rá Can - dom-blé vem da $B$ Ba- hi-

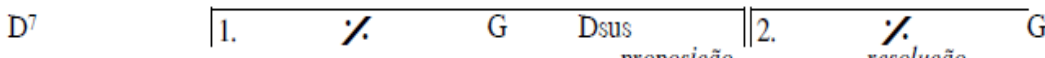

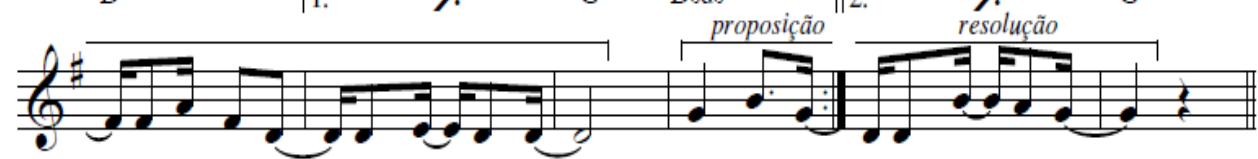

a on-de bai-xamoso - ri- xás_ A - re - rê xamos o - ri- xás_ 
Figura 4 - Refrão de "Oscarito, carnaval e samba, uma chanchada no asfalto", Império Serrano, 1978

"Oscarito, carnaval e samba, uma chanchada no asfalto", Império Serrano, 1978

(Nina Rodrigues / Aidno Sá/Ubirajara Cardoso)
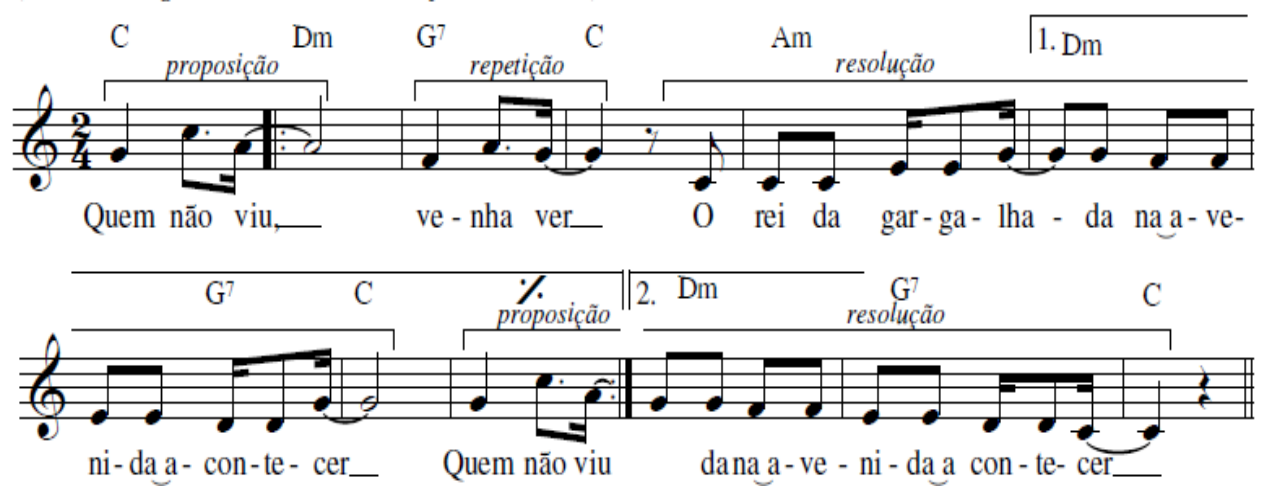

Figura 5 - Refrão de "Dique, um mar de amor", Vila Isabel, 1978

"Dique, um mar de amor", Vila Isabel, 1978

(Jarbas / Garganta de Ferro / Boanezio / Augusto Messias)

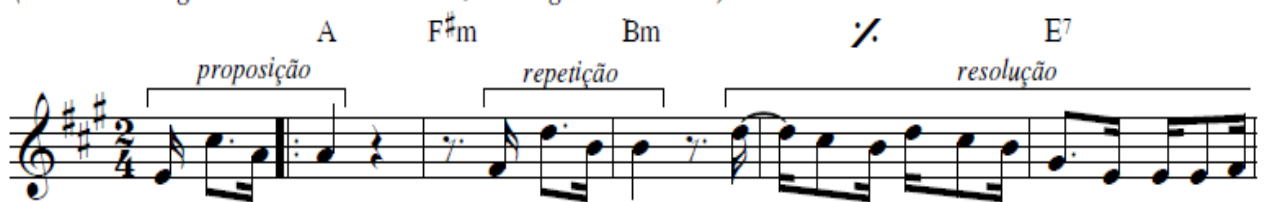

Chu-ê, chu - ê

Chu-ê, chu-á

As__on-das le-vam sa-vei- ros como-fe

\begin{tabular}{llll|l}
\hline 1. & $\%$ & $\mathrm{~A}$ & $\left(\mathrm{E}^{7}\right)$ & $\mathrm{A}$
\end{tabular}

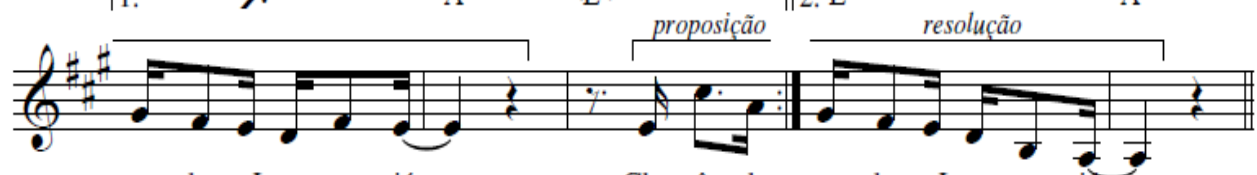

ren- das a I-e - man - já

Chu-ê, chu- ren-das a I-e-man- jấ 
Figura 6 - Refrão de "Mulher à brasileira", Portela, 1978

"Mulher à brasileira", Portela, 1978

(Jair Amorim / Evaldo Gouveia)

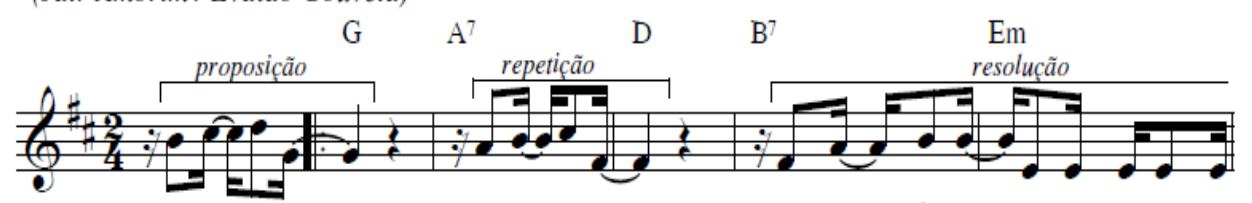
O-lê,-o-lê_ O-lê,-o-lá Po- dem. fa- lar_masmu-lherco-mo a

\begin{tabular}{|lll||lll}
\hline 1. & $\mathrm{A}^{7}$ & $\mathrm{Am}$ & $\mathrm{D}^{7}$ & $\mathrm{~A}^{7}$ & $\mathrm{D}$
\end{tabular}

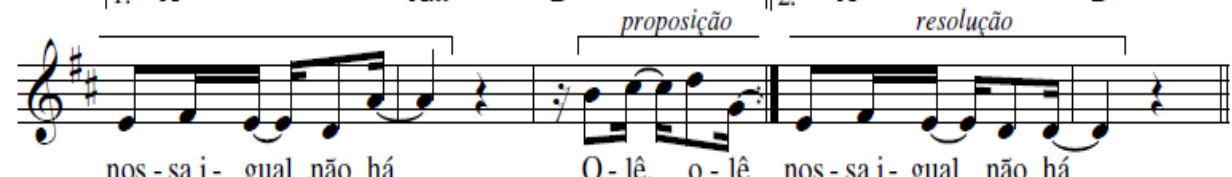

nos - sa i - gual năo há

0 - lê,_ 0 - lệ nos - sai- guaL năo há

O sucesso de Festa para um rei negro não havia passado despercebido pelos compositores: expressões como "Olê, olá" (Em cima da hora, 1975; Portela 1978), "Arerê, arerá" (Mocidade, 1976) e "Chuê, chuá" (Vila Isabel, 1978) são herdeiras do famoso "Olêlê, olálá" do samba do Salgueiro (Figura 7). A similaridade no plano poético também é correspondida no plano melódico, visto que a estrutura do refrão de Festa para um rei negro já apresentava proposição e repetição:

Figura 7 - Refrão de "Festa para um rei negro", Salgueiro, 1971

"Festa para um rei negro", Salgueiro, 1971 (Zuzuca)
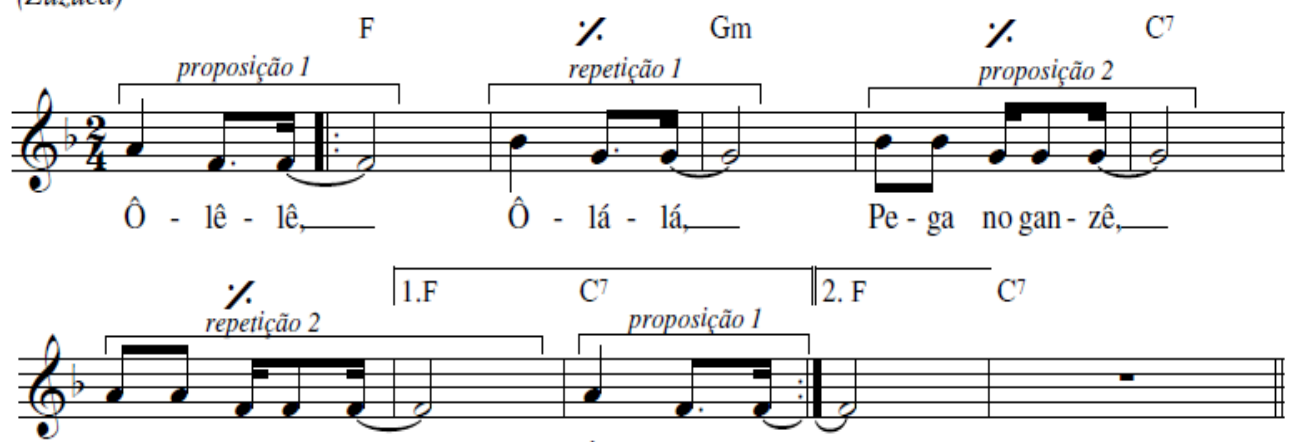

Pe - ga no gan - zá

Ô - lê - lê, 
Embora já possamos identificar uma forte tendência de padronização nos sambas-enredo da década de 1970, as obras das décadas seguintes seriam marcadas pela utilização ainda mais extensa de padrões harmônicos, melódicos e formais.

\section{Marcha-enredo}

No Manual do Julgador do Carnaval 2015, publicado pela Liga Independente das Escolas de Samba (LIESA), há uma orientação para que os jurados do quesito samba-enredo observem a adequação da obra apresentada às "características rítmicas próprias do samba" (Liesa, 2015, p. 40). As características mencionadas pelo Manual provavelmente são as mesmas mencionadas pela Carta do Samba, documento aprovado no I Congresso Nacional do Samba3, no qual consta que "o samba caracteriza-se pelo emprego da síncopa. Preservar as características tradicionais do samba significa, portanto, em resumo, valorizar a síncopa" (Carneiro, 1974, citado por Sandroni, 2001: 19).

No início da década de 1980, é possível notar um progressivo aumento da cometricidade nas linhas melódicas dos sambas-enredo, o que deu origem à classificação (pejorativa, ressalta-se) marcha-enredo para as obras em que a presença da sincopa está diminuída.

De acordo com Carlos Sandroni,

uma articulação rítmica será dita cométrica quando ocorrer na primeira, terceira, quinta ou sétima semicolcheia do $2 / 4$; e será dita contramétrica quando ocorrer nas posições restantes, à condição de não ser seguida por nova articulação na posição seguinte. Caso ocorra articulação em posição seguinte, ainda assim uma articulação nas posições pares poderá ser contramétrica, mas à condição de apresentar algum tipo de marca acentual (Sandroni, 2001, p. 27-28).

3 O I Congresso Nacional do Samba foi realizado na cidade do Rio de Janeiro entre os dias 28 de novembro a 2 de dezembro de 1962 (Sandroni, 2001: 19). 
No samba-enredo, essa tendência se manifesta especialmente nos refrões, muito provavelmente por conta da necessidade, nesses trechos, de um momento de explosão e comunhão entre todos os componentes da escola: (Figuras 8 a 12):

Figura 8 - Cometricidade em "No reino do faz de conta", Salgueiro, 1982

"No reino do faz de conta", Salgueiro, 1982

(Zé Di / César Veneno)

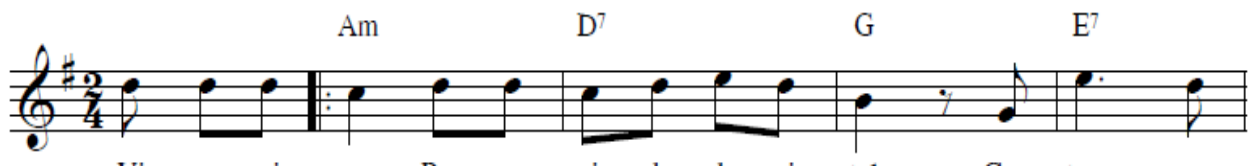

Vi - rou, vi - rou Pas - sa - ri - nho de cris - tal Can - tou, can -

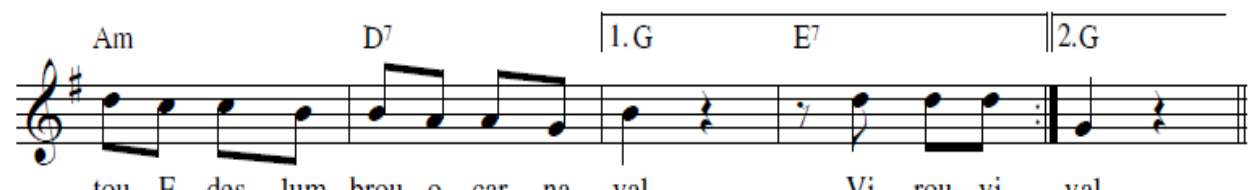

tou E des - lum-brou o car - na - val Vi - rou, vi - val

Figura 9 - Cometricidade em "Festa profana", União da Ilha, 1989

"Festa profana", União da Ilha, 1989

(J. Brito / Bujão)

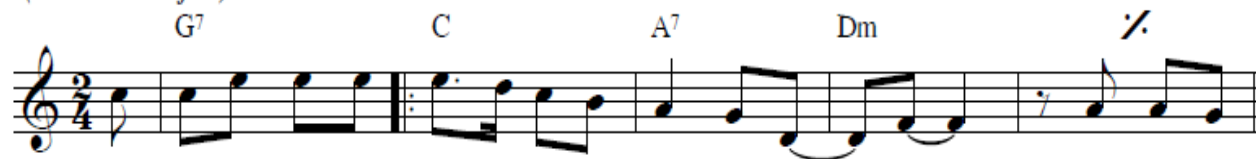

Eu vou to - mar um por - re de fe - li - ci-da - de__ Vou sa-cu-

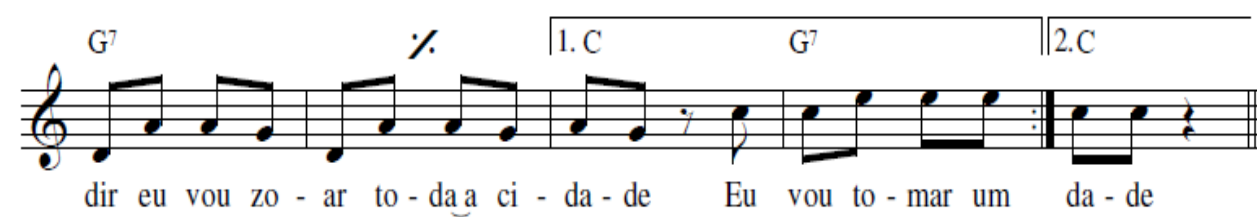


Figura 10 - Cometricidade em "Atrás da verde e rosa só não vai quem já morreu", Mangueira, 1994

"Atrás da verde e rosa só não vai quem já morreu", Mangueira, 1994

(David Corrêa / Paulinho Carvalho / Carlos Sena / Bira do Porto)

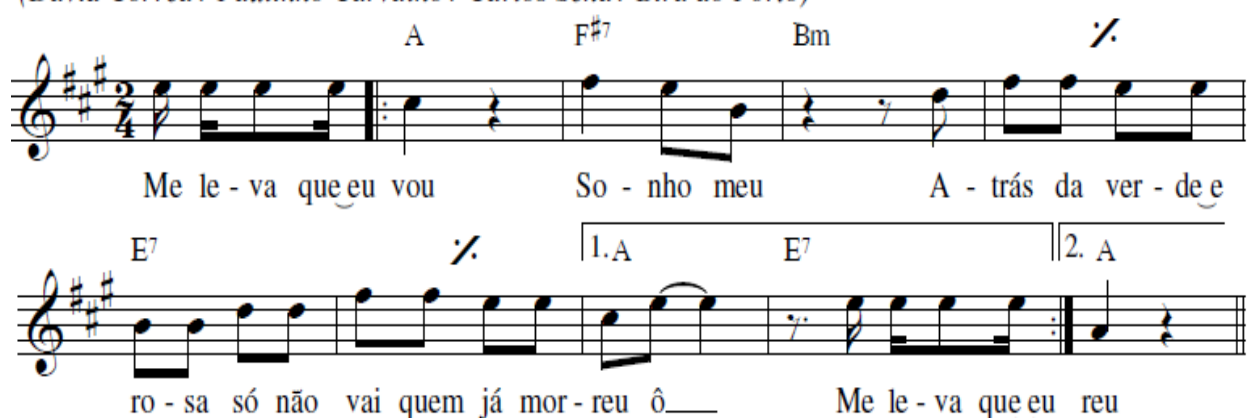

Figura 11 - Cometricidade em "Orfeu - O negro no carnaval", Viradouro, 1998

"Orfeu - O negro no carnaval", Viradouro, 1998

(Gilberto Gomes / R. Mocotó / Gustavo / P. C. Portugal / Dadinho)

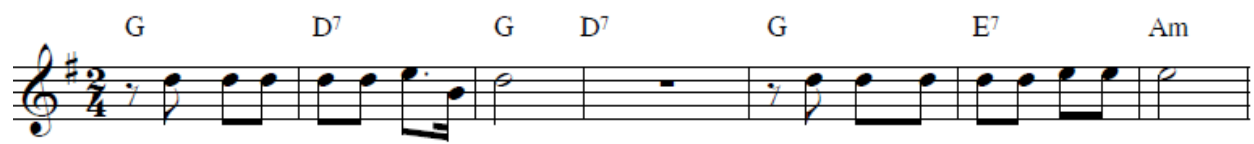

Ho-je o a-mor es-tá no ar

Vai con- quis- tar seu co - ra - çăo

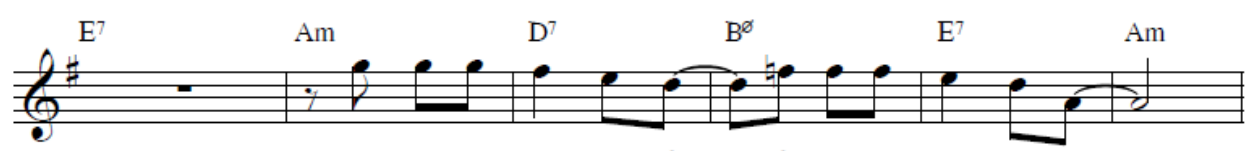

Tris - te - za năo tem fim,__ fe - li - ci - da - de, sim

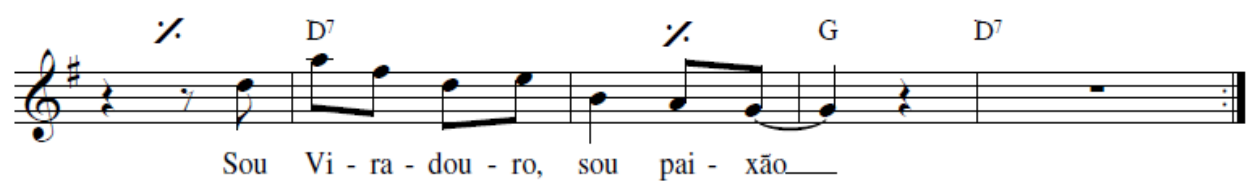


Figura 12 - Cometricidade em Nem todo pirata tem a perna de pau, o olho de vidro e a cara de mau..., Imperatriz Leopoldinense, 2003

"Nem todo pirata tem a perna de pau,

o olho de vidro e a cara de mau...", Imperatriz Leopoldinense, 2003

(Darcy do Nascimento / Brandãozinho / Rubens Napoleão / Jorge Rita)
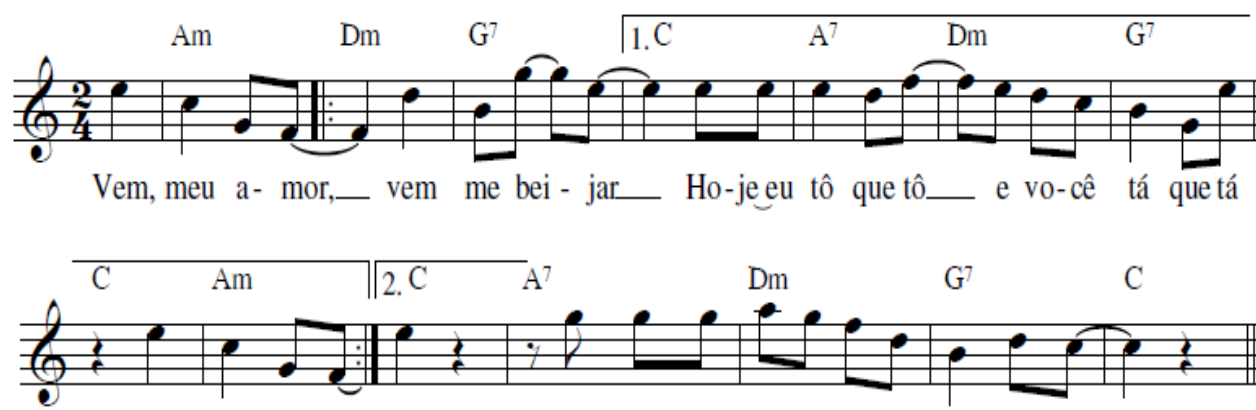

Vem, meu a-mor

Bei-jo es- con - di- do pra nin-guém clo - nar-

Uma das explicações para esse fenômeno está relacionada ao processo de gigantismo que acometeu as escolas a partir da década de 1970. Como o número de desfilantes crescia constantemente e o tempo de desfile não aumentava na mesma proporção, tornou-se necessário acelerar o andamento do samba para garantir a passagem de todos os componentes pela avenida no tempo especificado pelo regulamento 4 .

Márcio Coelho, em seu artigo Frevo-enredo: de como o sambaenredo tende a se tornar marchinha de carnaval, explica que "quando antecipamos um acento [síncopa], já estamos imprimindo velocidade a um arranjo rítmico" e que "ao acelerar[mos] o andamento de uma música, os pulsos ficam [ainda] mais próximos e, no limite, tendem a se conjungir, ou se fundir" (Coelho, 2009, p. 37). Ou seja, com a

4 Graças à Internet, pudemos ter acesso a trechos dos desfiles do carnaval das mais diversas épocas. Em 1972, por exemplo, verificamos que o andamento imposto pelas escolas girava em torno de 115 a $120 \mathrm{bpm}$ (batidas por minuto). Quinze anos depois, no carnaval de 1987, o andamento do desfile da Estácio de Sá (O tititi do sapoti) já ultrapassava 130 bpm. E no desfile de 2004, Breazail, da Imperatriz Leopoldinense, chega a ultrapassar a impressionante marca dos 150 bpm. 
diminuição do espaço sonoro, decorrente da aceleração excessiva, a execução da síncopa torna-se dificultada. É por essa razão que, no samba-enredo acelerado, cada tempo do compasso acaba sendo preenchido por duas colcheias, visto que essas, por sua própria estrutura simples (tempo forte e contratempo), podem admitir andamentos extremamente velozes sem prejuízo de sua execução.

Alberto Ikeda acredita que os "sambeiros", "membros das classes média e alta que se aproximam das escolas somente por ocasião dos desfiles" (Ikeda, 1990, p. 3) têm uma parcela de responsabilidade nesse fenômeno:

Não resta dúvida de que para os 'sambeiros' é mais fácil assimilar melodias sem 'ginga', já que estão acostumados ao quadradismo rítmico das marchinhas, ou até mesmo do rock, e preferem 'pular carnaval' a sambar (Ikeda, 1990, p. 4).

Para John Blacking, distinções entre inovações no sistema musical e mudanças do sistema "só podem ser propriamente feitas através da relação entre as variações nos processos e produtos musicais e as percepções e padrões de interação daqueles que usam a música" (Blacking, 1977: 19). Para os fins deste artigo, recorro ao depoimento do compositor Eduardo Medrado5, que em entrevista ao pesquisador comenta o fenômeno de aceleração do andamento:

Antigamente o samba-enredo recobria o enredo e tinha uma pretensão que não se esgotava na animação. A partir de um determinado momento, há uma exigência implícita para que o samba-enredo seja o vetor da animação do desfile da escola (Medrado, 2009, entrevista ao pesquisador).

\footnotetext{
5 Eduardo Medrado, 51 anos. Compositor com sambas apresentados em desfile pela Imperatriz Leopoldinense (1995 e 1999) e Paraíso do Tuiuti (2001).
} 
Gusttavo Clarão ${ }^{6}$ tem uma opinião ligeiramente diferente:

Creio que [o fenômeno de aceleração] é uma tendência. O sambaenredo acompanhou o ritmo da bateria, acelerando junto com a mesma. Nada que seja definitivo, pois tenho observado nos últimos anos que tem havido uma desaceleração. Acho o meio termo [entre lento e rápido] o ideal (Clarão, 2009, entrevista ao pesquisador).

Questionado se concorda com a afirmação de que o sambaenredo hoje estaria perdendo suas características próprias ${ }^{7}$, Clarão responde: "Se você quer dizer que o samba perdeu a melodia, não concordo. O que ocorreu foi essa aceleração no andamento que dá essa falsa ideia" (Clarão, 2009, entrevista ao pesquisador).

De qualquer forma, pesquisadores e sambistas são unânimes em reconhecer que a aceleração do andamento acarretou mudanças estruturais no samba-enredo do período, ao menos no que diz respeito ao aspecto rítmico.

\section{Figuras de preenchimento}

Algumas das estruturas encontradas nos sambas-enredo do período aqui abordado se tornaram bastante disseminadas em um curto espaço de tempo. Esse é o caso das figuras de preenchimento, células rítmicas cuja função é preencher o espaço, antes ocupado por pausas, entre duas frases musicais. Não devemos confundi-las com os

6 Gusttavo Clarão, 45 anos. Compositor com sambas apresentados em desfile pela Estácio de Sá (1989, 2010), Unidos do Viradouro (1998, 1999, 2000, 2001, 2002, 2003, 2005, 2007) e Mangueira (2009).

7 Muitos comentaristas e pesquisadores de carnaval, ainda apegados a ideia de síncopa como elemento característico do samba, tendem a considerar a cometricidade como um elemento descaracterizador do samba-enredo. Entretanto, não seria o caso de repensarmos a própria classificação de sambaenredo já levando em conta esse fenômeno que há mais de 30 anos se manifesta nas composições? 
preenchimentos realizados pelos intérpretes (também chamados de cacos): estes geralmente têm caráter improvisatório e não são cantados pelos componentes da escola ou intérpretes auxiliares, ao passo que as figuras de preenchimento são consideradas uma parte constitutiva da linha melódica do samba. De qualquer maneira, a origem dessas figuras parece estar na necessidade de os compositores integrarem o que somente era privilégio dos intérpretes ao plano melódico fixo.

Embora John Blacking afirme que "mudanças musicais são causadas por decisões feitas por indivíduos sobre o fazer musical com base em suas experiências e atitudes em relação à música em diferentes contextos sociais" (Blacking, 1977, p. 12), é difícil estabelecer, em gêneros de música popular, qual compositor teve a primazia de utilizar uma determinada estrutura musical. A atribuição de uma data de surgimento de um novo padrão tendo como base a primeira vez em que é registrado em disco, como é o caso do modelo de refrão de Festa para um rei negro acima mencionado, pode se revelar enganosa, na medida em que ele pode ter sido aprendido oralmente por um compositor a partir de um samba concorrente de anos anteriores não escolhido para o desfile ${ }^{8}$ e, consequentemente, não ter sido registrado em disco.

De qualquer forma, embora tenha se tornado prática corrente em meados da década de 1980, as figuras de preenchimento podiam ser ouvidas já no final da década de 1970, como é o caso do samba de 1979 da Mocidade Independente de Padre Miguel (Figura 13):

\footnotetext{
8 Cada escola de samba realiza disputas internas para decidir qual o sambaenredo que será entoado por seus componentes no dia de desfile. Os sambas perdedores, salvo raras exceções, jamais são tocados nos ensaios da escola novamente, e entram para o "cemitério de sambas mortos", segundo expressão utilizada por Maria Julia Goldwasser (Goldwasser, 1975: 100). O advento da internet, entretanto, tem se mostrado benéfico para a construção de uma memória mais ampla do samba-enredo, na medida em que as obras concorrentes são disponibilizadas ao público em sites especializados em carnaval, e os visitantes podem ter acesso ilimitado a sambas que, em outras épocas, seriam relegados ao esquecimento.
} 
Figura 13 - Figura de preenchimento em "O descobrimento do Brasil", Mocidade Independente, 1979

"O descobrimento do Brasil", Mocidade Independente, 1979

(Tôco / Djalma Crill)

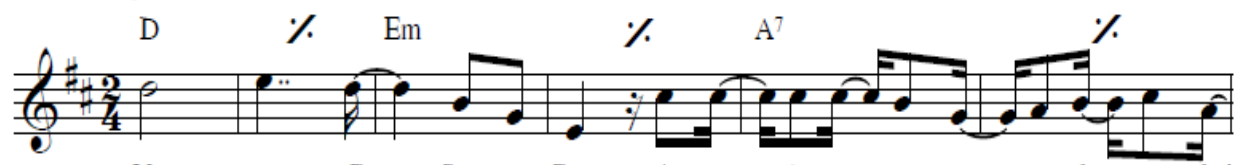

$\mathrm{Ve}$ - ra Cruz, San-ta Cruz A- que - le na-ve- gan - te des-co-briu

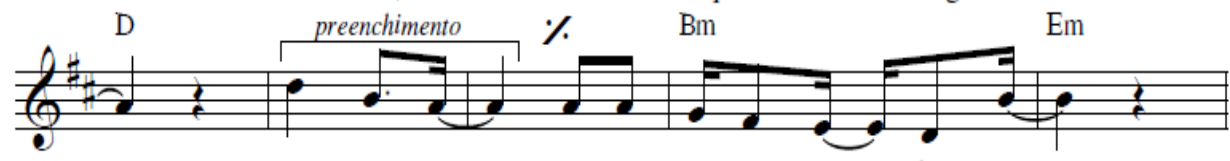

- (des - co- briu) E de - pois se trans - for - mou

A divisão rítmica mais comum da figura de preenchimento é a seguinte (Figura 14):

Figura 14 - Modelo padrão de figura de preenchimento

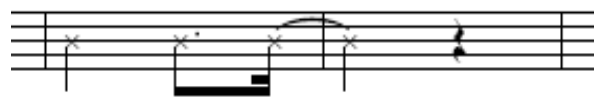

É evidente que a presença dessa divisão não implica em sua classificação como figura de preenchimento. Para que seja considerada como tal, a letra que a reveste deve ser uma repetição da(s) última(s) palavra(s) do verso antecedente ou, pelo menos, fazer referência a ele 9 . Isso evidencia sua função como preenchimento e não como um novo elemento para a compreensão do enredo (Figuras 15 a 20):

9 Dessa forma, as figuras de preenchimento, ao fazerem referência a um verso passado, atuam de maneira inversa à tradição dos cantores de samba de anunciar os versos que serão imediatamente cantados. 
Figura 15 - Figura de preenchimento em "Adolã, a cidade-mistério", Imperatriz Leopoldinense, 1985

"Adolã, a cidade-mistério", Imperatriz Leopoldinense, 1985

(C. Sideral / Doutor / Amaurizão / Guga)
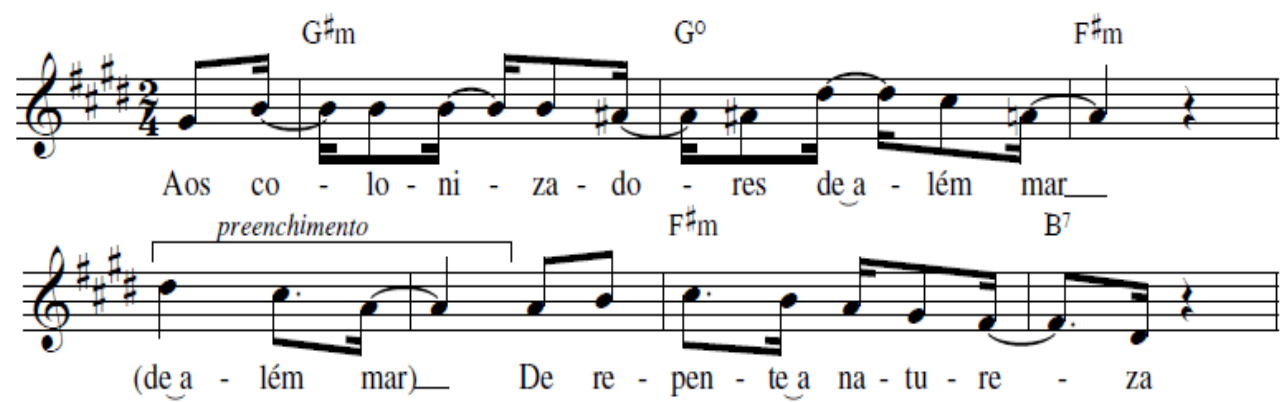

Figura 16 - Figura de preenchimento em "Eu quero", Império Serrano, 1986

"Eu quero", Império Serrano, 1986

(Aluísio Machado / Luiz Carlos do Cavaco / Jorge Nóbrega)

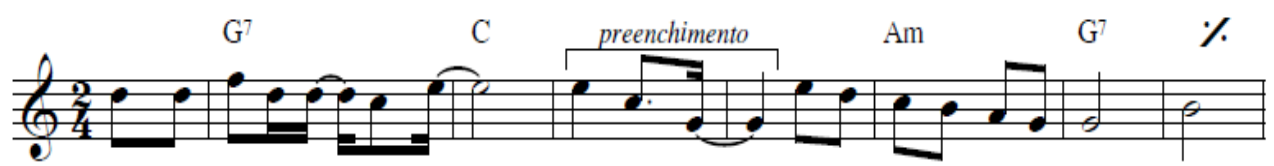

Se-ja umho-je bem_me- lhor_ (bem me- lhor)_ U-ma ju-ven-tu-de să

Figura 17 - Figura de preenchimento em "Cama, mesa e banho de gato", Unidos da Tijuca, 1986

"Cama, mesa e banho de gato", Unidos da Tijuca, 1986

(Carlinhos Anchieta / Vicente das Neves / Manelzinho Poeta / Azeitona)

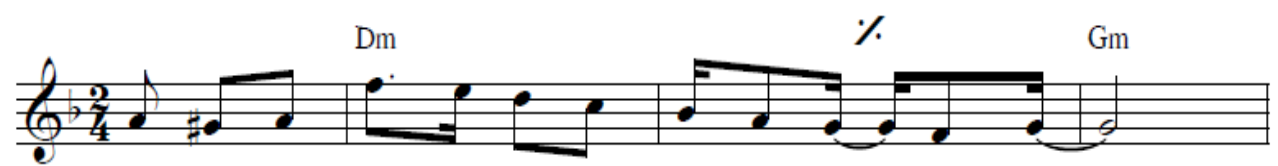

Mas o co - zi - do da vi - zi - nha é_ me - lhor_

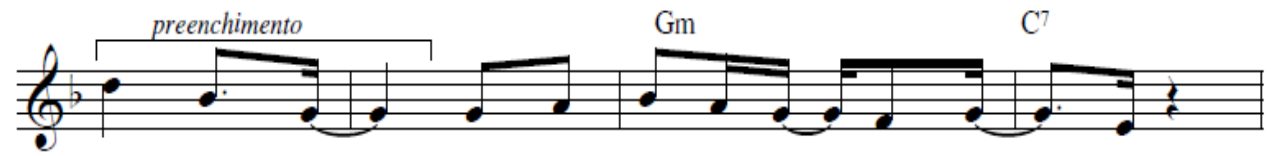

(é me - lhor _ Di - zem que eu sou_ ma - chis - ta 
Figura 18 - Figura de preenchimento em "Sou negro, do Egito à liberdade", Beija-Flor, 1988

"Sou negro, do Egito à liberdade", Beija-Flor, 1988

(Ivancué / Cláudio Inspiração / Marcelo Guimarães / Aloísio Santos)

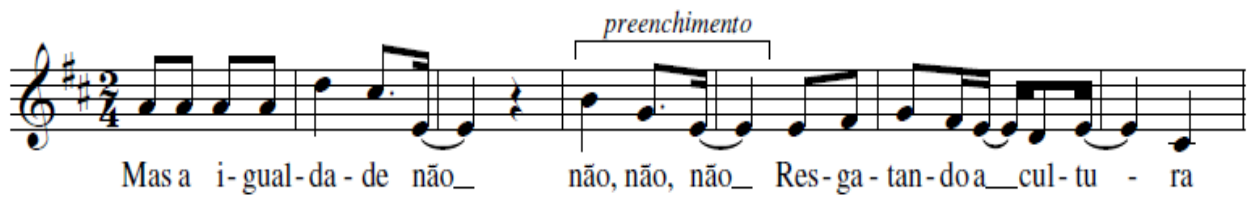

Figura 19 - Figura de preenchimento em "Uni-duni-tê, a Beija-Flor escolheu: é você!", Beija-Flor, 1993

"Uni-duni-tê, a Beija-Flor escolheu: é você!", Beija-Flor, 1993

(Wilson Bombeiro / Edeor de Paula / Sérgio Fonseca)

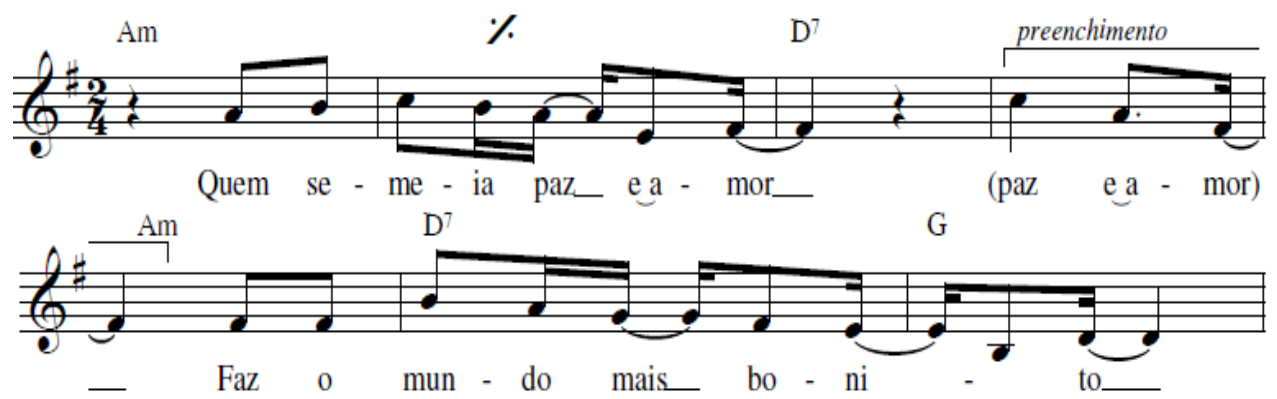

Figura 20 - Figura de preenchimento em "Aquarela do Brasil ano 2000", Viradouro, 1996

"Aquarela do Brasil ano 2000", Viradouro, 1996

(Heraldo Faria / Jorge Baiano / Mocotó / Flavinho Machado)

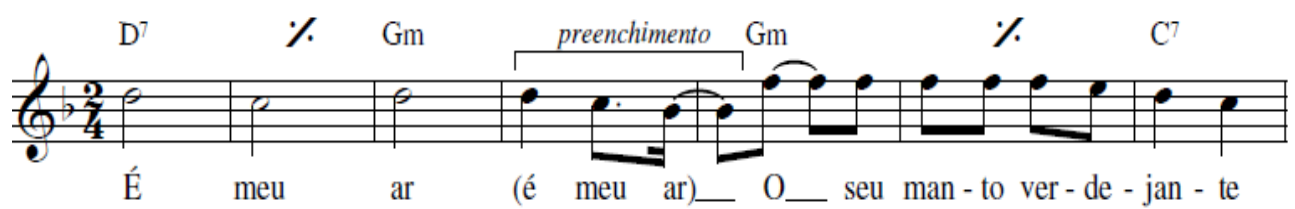

A utilização das figuras de preenchimento diminuiu consideravelmente no final dos anos 1990, estando hoje em dia 
praticamente em desuso. O samba abaixo foi um dos últimos que ainda se valeram dela (Figura 21 ):

Figura 21 - Figura de preenchimento em "Salgueiro no mar de Xarayés", Salgueiro, 2001

"Salgueiro no mar de Xarayés", Salgueiro, 2001

(Augusto / Zé Carlos do Saara / Rocco Filho / Nego)

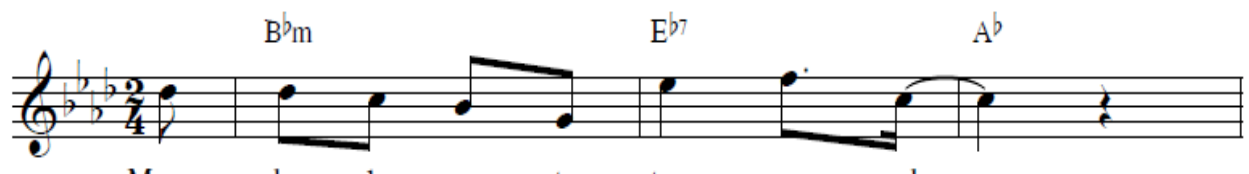

Me em - ba - la nes - te teu so - nhar

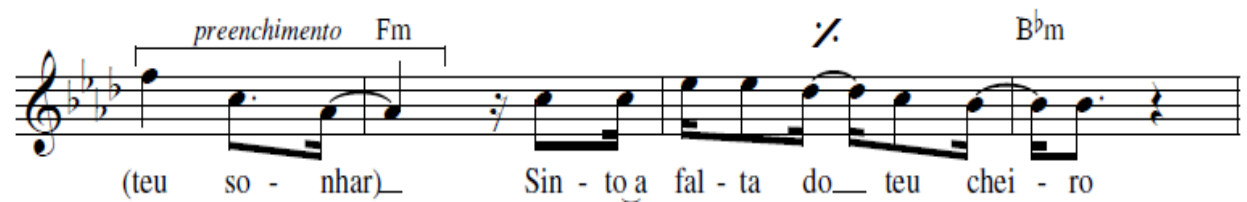

Portanto, podemos classificar essa estrutura como típica da década de 1980 e não como característica do samba-enredo como um todo ${ }^{10}$, ou nos termos de Blacking, como uma variação no interior do sistema sem maiores consequências para uma mudança estrutural do gênero.

\section{Tonalidades homônimas e refrões responsoriais}

A prática de modulação entre tonalidades homônimas cresceu enormemente no samba-enredo das últimas três décadas. Atualmente, são raros os sambas construídos em apenas um modo (maior ou menor): no ano de 2015, por exemplo, nove dos doze sambas das escolas do Grupo Especial do Rio de Janeiro fizeram uso dessa forma de modulação.

10 Chamo de características as estruturas que se mantém largamente utilizadas no samba-enredo através dos tempos, independente da época ou estética dominante. Já as estruturas ligadas a um determinado período, como as figuras de preenchimento, podem ser chamadas de típicas. 
De acordo com a definição de Luiz Tatit (2000: 3), "o sambaenredo é um 'gênero-fluxo', com melodia que sai ao encalço da letra, suplantando toda a sorte de entraves silábicos para garantir a evolução de uma história preestabelecida". A modulação, portanto, pode ajudar a conferir diversidade à melodia do samba-enredo, que necessita constantemente de elementos de variação para evitar a monotonia.

É importante frisar que desde a década de 1960 já era possível encontrar sambas que se valiam desse procedimento (Figuras 22 a 24):

Figura 22 - Modulação em "Os cinco bailes da história do Rio", Império Serrano, 1965

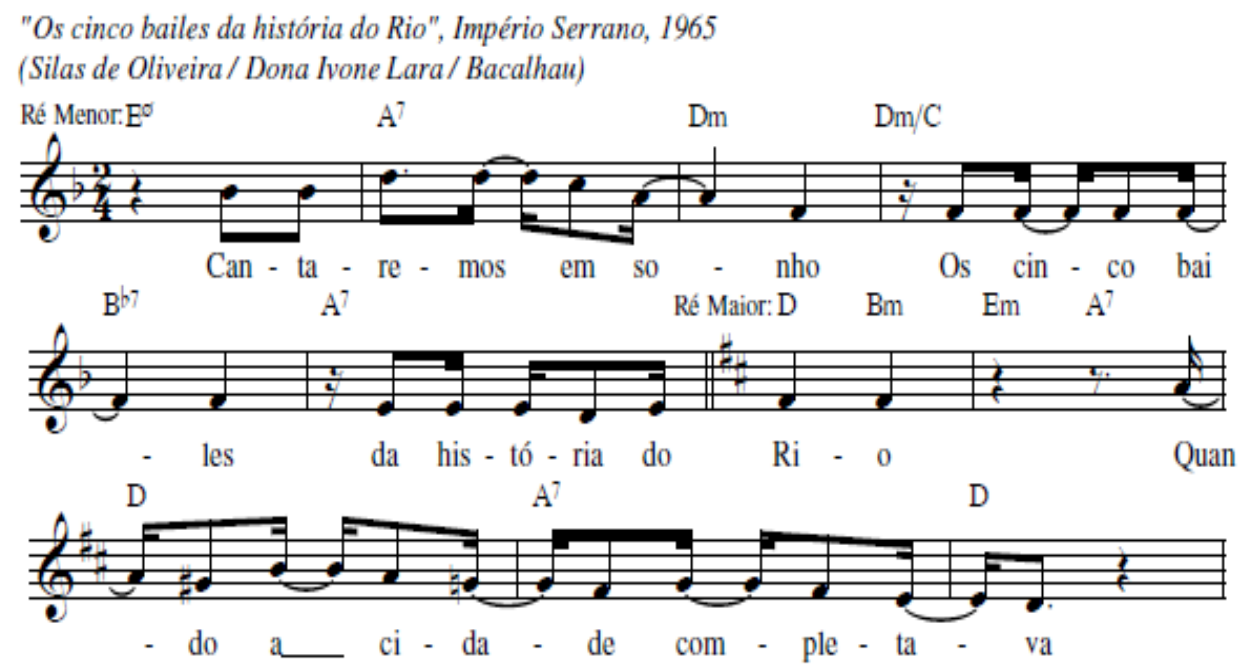


Figura 23 - Modulação em "Viagem pitoresca através do Brasil", Mocidade Independente, 1968

"Viagem pitoresca através do Brasil", Mocidade Independente, 1968

(Da Roça / Djalma)

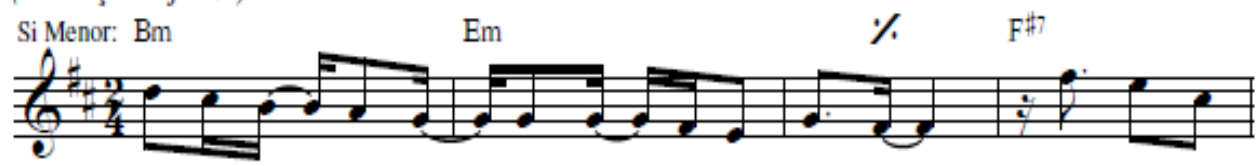

E - ra dis - pu - ta - da a pre - ço de ou - ro__ Pe - la mais
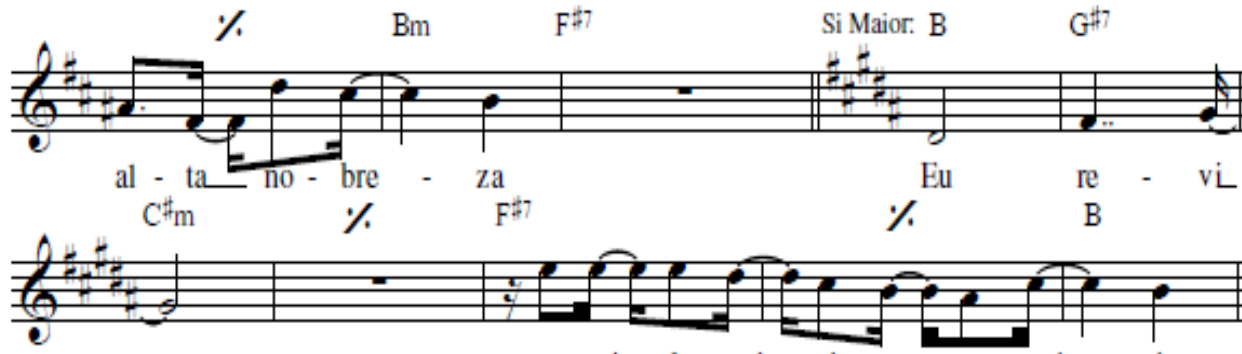

na mi - nha mú - si - ca a_ me - mó - ria

Figura 24 - Modulação em "Brasil, flor amorosa de três raças", Imperatriz Leopoldinense, 1969

"Brasil, flor amorosa de três raças", Imperatriz Leopoldinense, 1969

(Mathias de Freitas / Carlinhos Sideral)

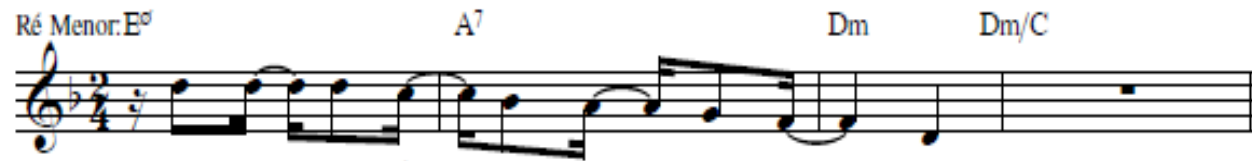

Bo - tão_ em flor_ cres - cen - doum di - a

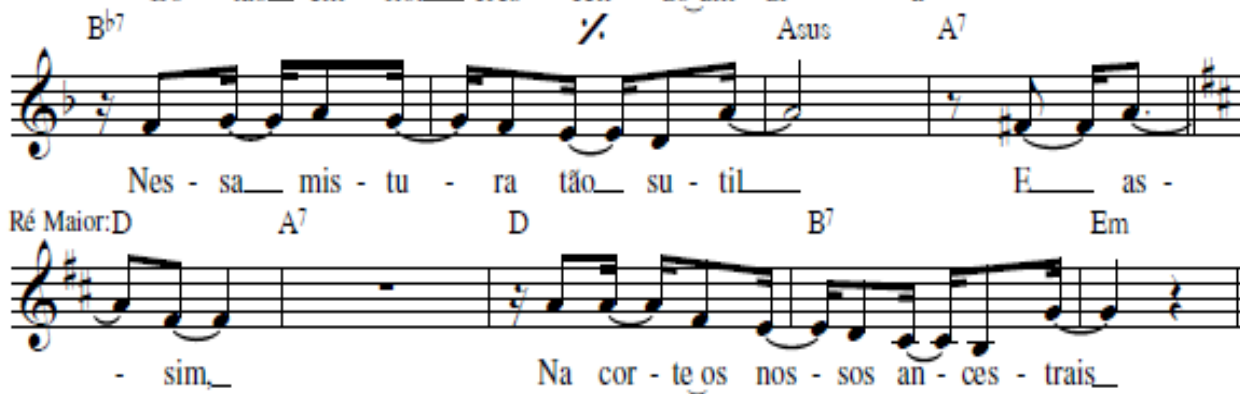

A partir da década de 1990, a utilização dessa técnica já estava tão disseminada que em alguns casos a tonalidade inicial é sustentada 
por poucos compassos para logo ser transformada em sua homônima (Figuras 25 a 28):

Figura 25 - Modulação em "Os olhos da noite", Portela, 1998

"Os olhos da noite", Portela, 1998

(Noca da Portela / Colombo / J. Rocha / Darcy Maravilha / Celino Dias)

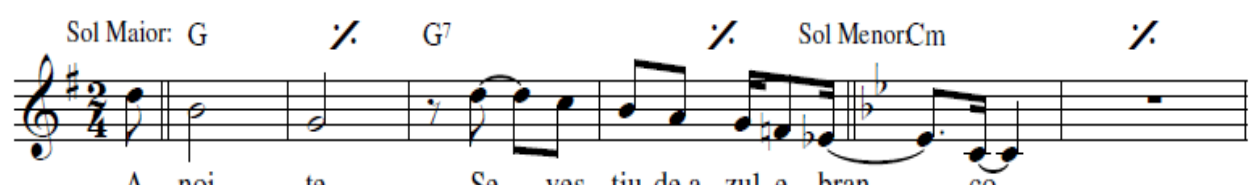
A noi - te
Se_ ves - tiu de a-zul e bran
$\% \quad \mathrm{Gm}$

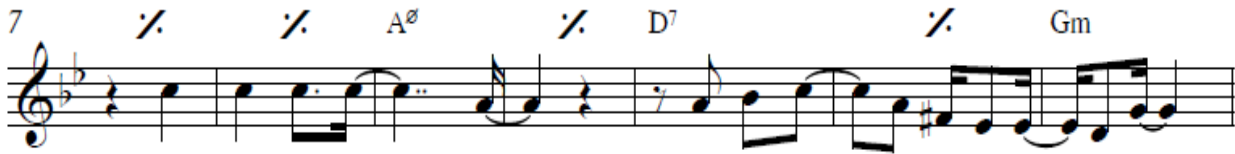

A - briu seu man - to__ Comen- can - to e po-e-si - a

Figura 26 - Modulação em "Viradouro, Vira-Mundo, Rei do mundo", Viradouro, 2002

"Viradouro, Vira-Mundo, Rei do mundo", Viradouro, 2002

(Gilberto Gomes / R. Mocotó / Gustavo / P.C. Portugal / Dadinho)

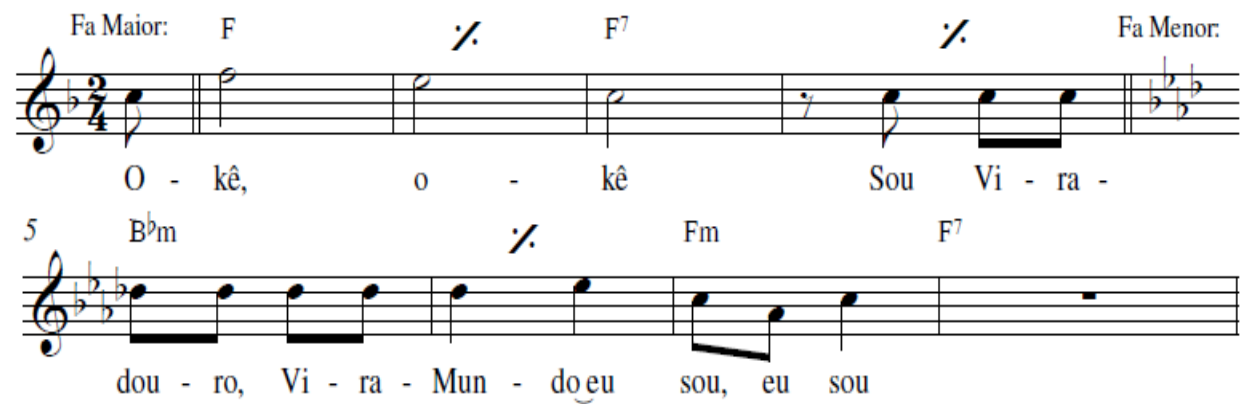


Figura 27 - Modulação em "O Quinto Império", Mocidade Independente, 2008

"O Quinto Império - De Portugal ao Brasil, uma utopia na história", Mocidade Independente, 2008

(Marquinho Marino / Gustavo Henrique / Igor Leal)

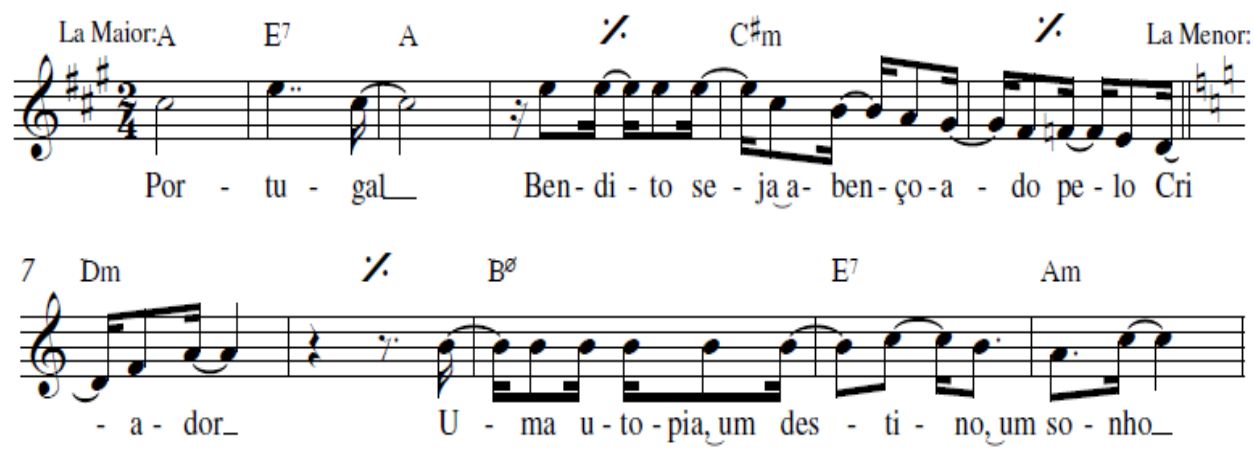

Figura 28 - Modulação em "Imperatriz... só quer mostrar que faz samba também", Imperatriz Leopoldinense, 2009

"Imperatriz... só quer mostrar que faz.

samba também", Imperatriz Leopoldinense, 2009

(Josimar / Jorge Arthur / Valtenci / Di Andrade / Carlos Kind)

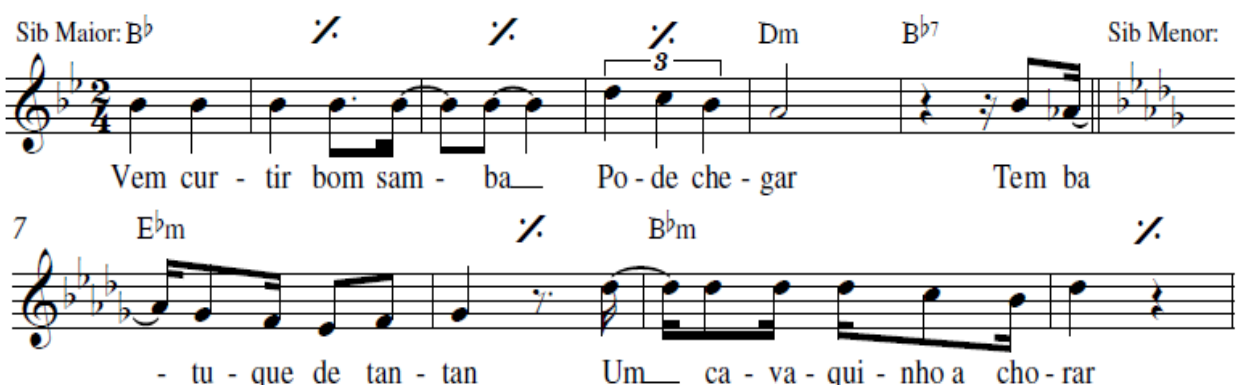

Os refrões se tornaram um território especialmente fértil para a realização de modulações (Figuras 29 a 31): 
Figura 29 - Modulação em "Muito prazer! Isabel de Bragança e Drummond Rosa da Silva, mas pode me chamar de Vila", Vila Isabel, 1994

\section{"Muito prazer! Isabel de Bragança e Drummond}

Rosa da Silva, mas pode me chamar de Vila", Vila Isabel, 1994

(Vilani Silva "Bombril" / Evandro Bocão / André Diniz)

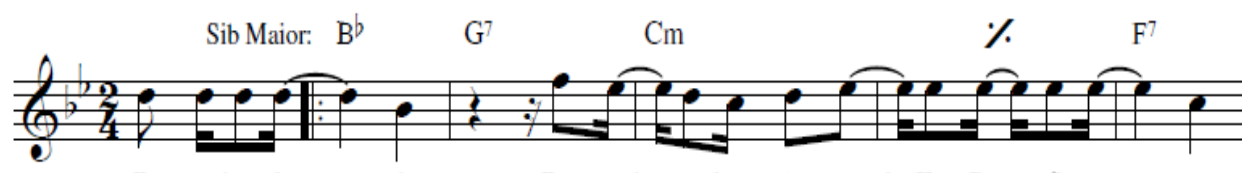

Pe-guei 0 bon - de

Pas - sei_no bou- le- vard_Ea Con - fi- an - ça

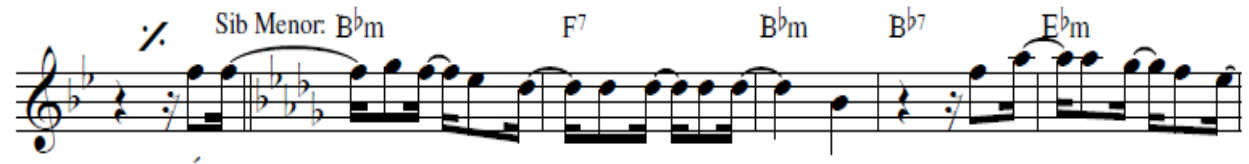
É do - ce re-cor- dar_Os "três a-pi - tos" can-ta - dos porNo-el

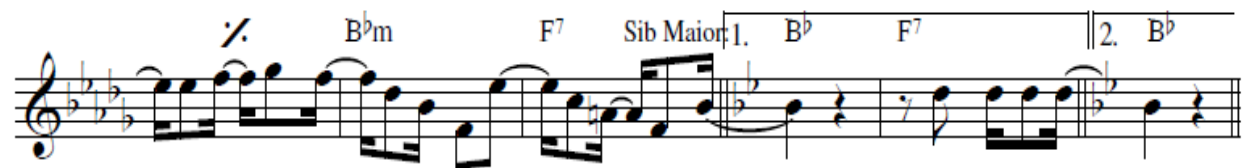

— a- in-da e- co - ampe-la Vi - la I - sa- beL__ Pe-gueiobon-

Figura 30 - Modulação em "Goiás, um sonho de amor no coração do Brasil", Caprichosos de Pilares, 2001

"Goiás, um sonho de amor no coração do Brasil", Caprichosos de Pilares, 2001 (Jorge 101 / Luiz Pião / Gule / Lequinho)

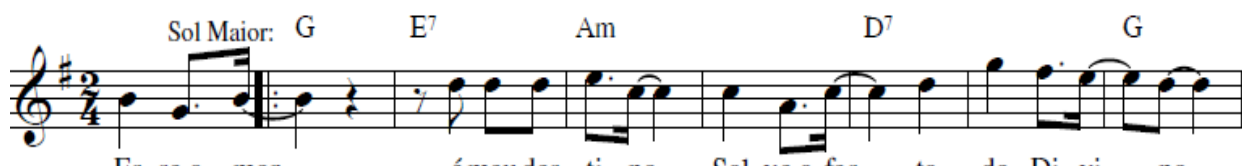

Es-se a- mor_ émeudes - ti-no_ Sal-vea fes - ta do Di-vi - no_

$\mathrm{D}^{7} \quad$ Sol Menor: $\mathrm{Gm}$

$\mathrm{G}^{7}$

$\mathrm{Cm}$

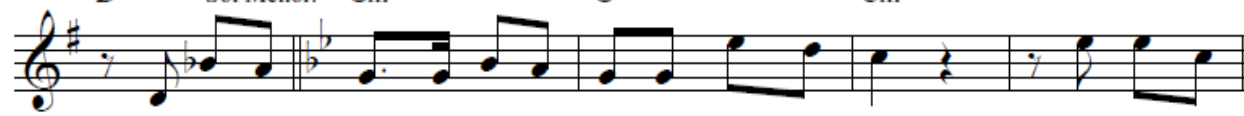

Na ca - va - lha - da a lu - ta do bem con - tra o mal

A - pai - xo-

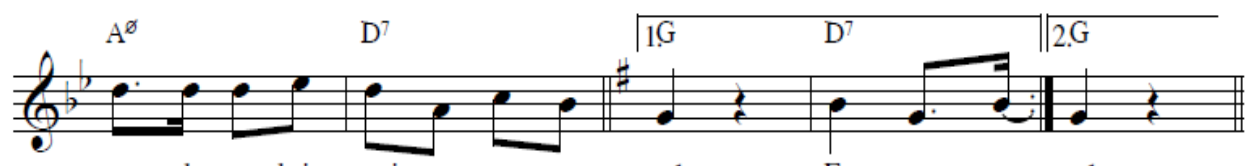

na - do, eu brin-quei seu car - na - val

Es - se a - mor val 
Figura 31 - Modulação em "Manoa, Manaus, Amazônia, Terra Santa: Alimenta o corpo, equilibra a alma e transmite a paz", Beija-Flor, 2004

"Manoa, Manaus, Amazônia, Terra Santa: alimenta o corpo, equilibra a alma e transmite a paz", Beija-Flor, 2004 (Claudio Russo / José Luis / Marquinhos / Jessey Beija-Flor)

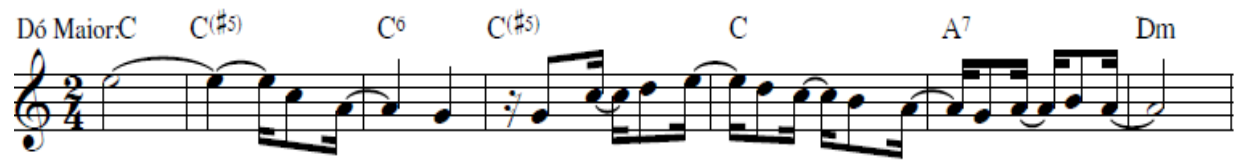

Eh!_ Ma- no - a Mi- nha ca- no - a vaicru-zar_o Ri-o Mar_
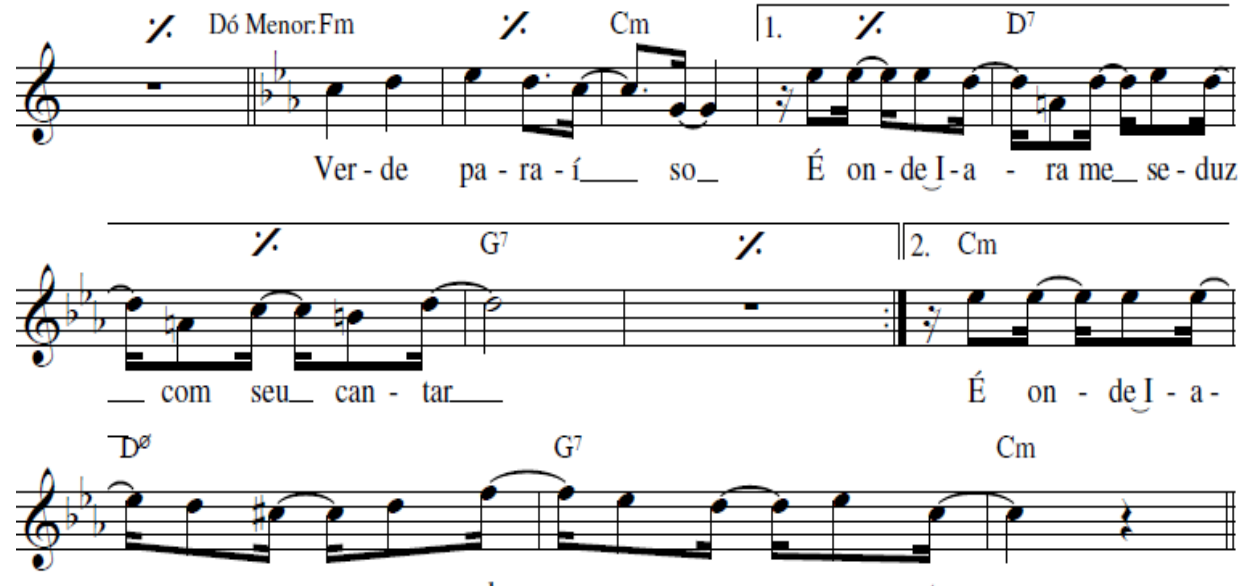

- ra me_ se - duz_ com seu_ can - tar

Já os refrões responsoriais, assim chamados por conta de seu formato de "pergunta e resposta", começaram a ser percebidos em grande escala a partir da década de 1990 (e para isso muito contribuiu o imenso sucesso de Peguei um Ita no Norte, samba do Salgueiro de 1993 popularmente conhecido como Explode coração) e seguem sendo bastante utilizados nos dias de hoje. Sua organização interna é feita da seguinte maneira:

1) apresentação de uma frase musical composta por dois membros: pergunta (o maior deles) e resposta (sempre de curta duração). Estes são separados por pausa ou nota de longa duração pertencente à pergunta;

2) uma ou duas repetições variadas dessa frase; 
3) frase intermediária (em alguns casos) frequentemente sugerindo o elemento responsorial;

4) frase conclusiva (resolução).

Refrões como esses estão abaixo citados. Cabe notar que quase todos compartilham a mesma sequência harmônica. Além disso, é notável o número de vezes em que as rimas "eu vou" e "amor" aparecem nas respostas, o que indica que a padronização no plano musical também era respondida no plano poético (Figuras 32 a 35):

Figura 32 - Refrão responsorial em "Peguei um Ita no Norte", Salgueiro, 1993

"Peguei um Ita no Norte", Salgueiro, 1993

(Demá Chagas, Arizão, Bala, Guaracy e Celso Trindade)

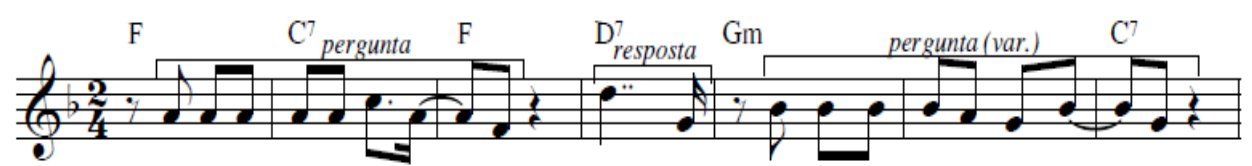
Oi,no ba-lançodas on - das eu vou Nomar eu jogoasau- da - de,

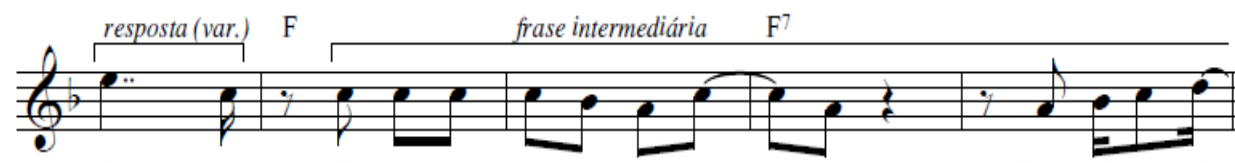
A - mor 0 tem-po traz es - pe - ran - ça Ean-si-e - da

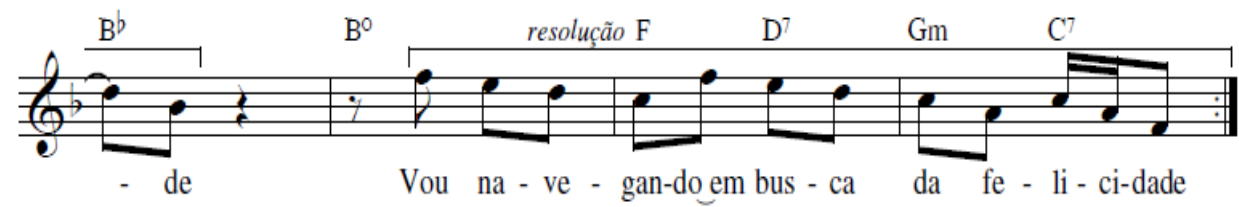


Figura 33 - Refrão responsorial em "Na era dos Felipes o Brasil era espanhol", Grande Rio, 1996

"Na era dos Felipes o Brasil era espanhol", Grande Rio, 1996

(Barbeirinho / Bebeto do Arrastão / Jailson da Grande Rio)
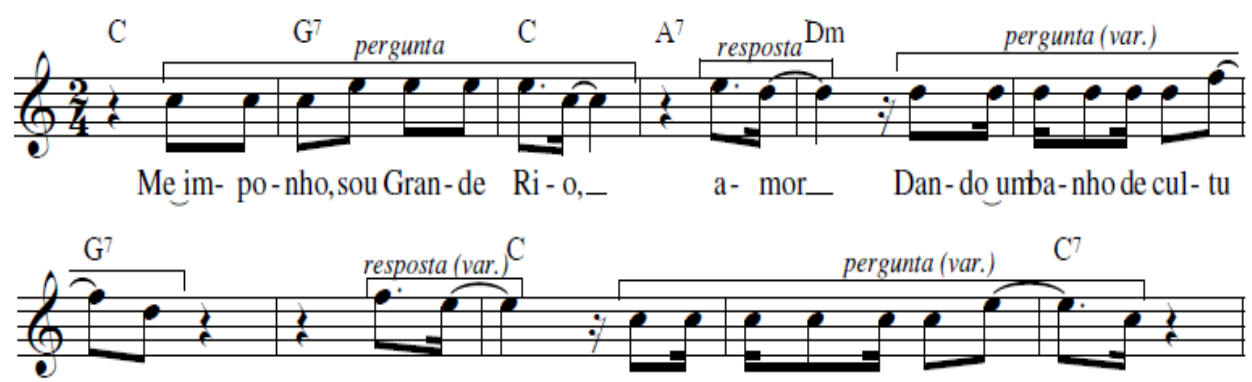

- ra, eu vou $\quad$ Pro a - bra - ço da ga - le - ra

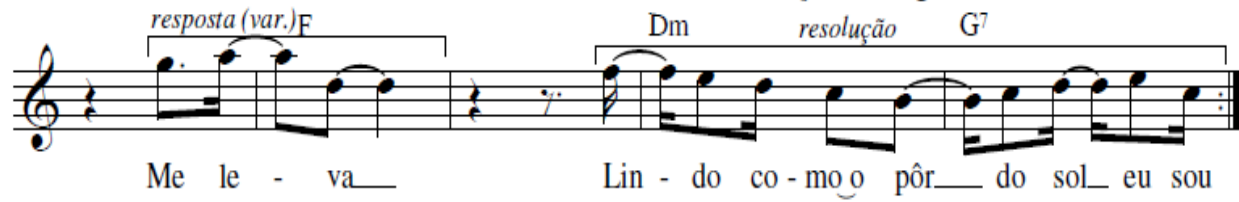

Figura 34 - Refrão responsorial em "Samba no pé e mãos ao alto, isto é um assalto", Porto da Pedra, 1998

"Samba no pé e mãos ao alto, isto é um assalto!", Porto da Pedra, 1998 (Índio do Império / Tião Telles / Paulo Roberto / Jorge Dodi)
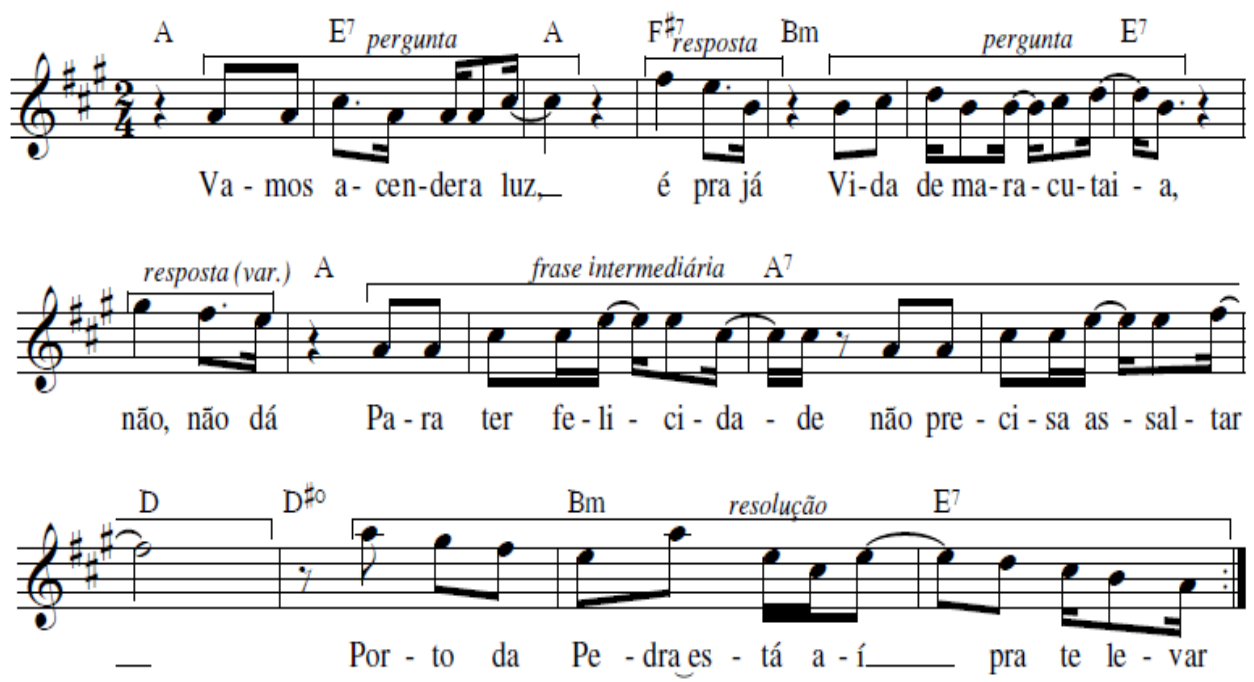
Figura 35 - Refrão responsorial em "Do universo teatral à ribalta do carnaval", Santa Cruz, 2003

"Do universo teatral à ribalta do carnaval", Santa Cruz, 2003

(Doutor / Eli Penteado / Jorge Charuto / Marquinho Bombeiro / Fernando de Lima)

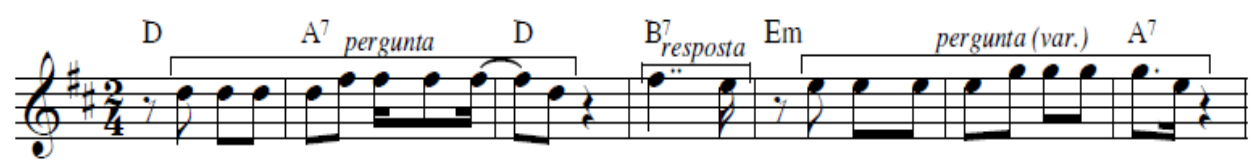

Tem pi-er - rô e co-lom-bi - na, a - mor 0 cir-coencan-tame fas-ci-na,
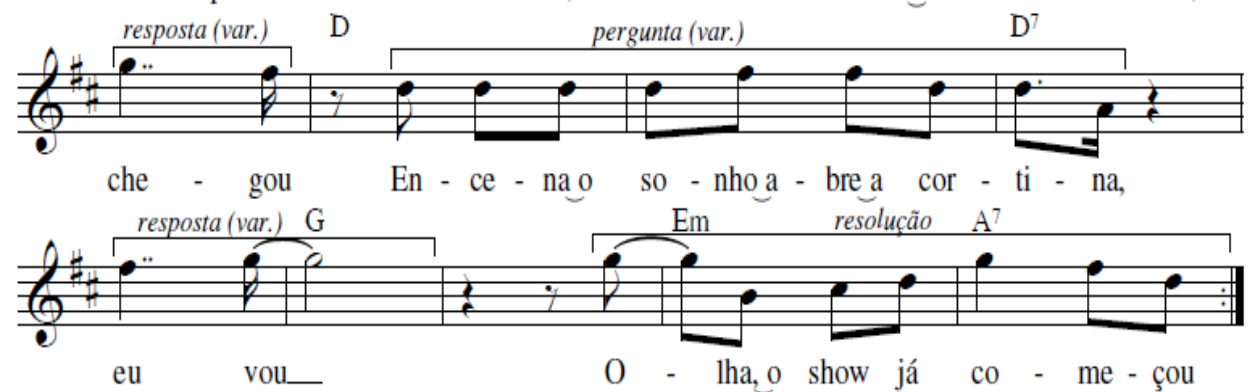

Do mesmo modo que as figuras de preenchimento, os procedimentos acima descritos não representam uma mudança profunda nos modos de produção e performance do samba-enredo, já que a prática de modulação entre tonalidades homônimas já estava presente no gênero desde a década de 1960 - ainda que em menor dimensão -, e os refrões responsoriais dizem respeito a momentos localizados do samba, e não à composição como um todo.

\section{Padrão formal}

De uma maneira geral, a música das escolas de samba sempre se mostrou versátil no que diz respeito ao plano formal. Nas primeiras décadas de desfile a música das escolas se valia da forma binária (A-B); posteriormente, na era dos sambas-lençóis (décadas de 1950 e 1960), adquiriu estruturas mais complexas, de maior extensão (sambas com 
mais de uma centena de compassos tornaram-se comuns) e divisão em várias partes; e se valeu, nos anos 1970, de um número variado de refrões e até mesmo prescindiu deles ${ }^{11}$.

Apesar da pluralidade de formas possíveis de serem aplicadas ao samba-enredo, é possível notar, no período aqui estudado, a preferência da maioria dos compositores por um único padrão formal (Figura 36):

Figura 36 - Padrão formal

\section{PRIMEIRA PARTE \\ REFRÃO CENTRAL \\ SEGUNDA PARTE \\ REFRÃO PRINCIPAL}

$\mathrm{Na}$ verdade, essa estrutura é antes uma forma poética do que uma forma musical, já que cada uma dessas quatro divisões corresponde a uma estrofe. Isso significa que cada estrofe pode conter mais de uma parte musical12, ou, melhor dizendo, duas ou mais partes musicais podem estar contidas na primeira ou na segunda partes poéticas. Obviamente, cada um dos refrões, dado o seu caráter conciso, corresponde a apenas uma parte musical.

Portanto, tendo como base a forma poética padrão, um sambaenredo poderia ser organizado hipoteticamente das seguintes maneiras (Figuras 37 e 38):

11 Esse é o caso de dois sambas da Mangueira: Mangueira em tempo de folclore (1974) e Parapanã, o segredo do amor (1977).

12 A divisão de partes aqui apresentada procura levar em conta eventos como a ocorrência de cadências, modulações ou a unidade rítmica-melódica de um trecho. 
Figura 37 - Relação estrita entre as formas poética e musical

\begin{tabular}{lllll}
\hline FORMA POÉTICA: & A (1" parte) & B (refrão central) & C (segunda parte) & D (refrão principal) \\
FORMA MUSICAL: & A & B & C & D \\
\hline
\end{tabular}

Figura 38 - Relação flexível entre as formas poética e musical

\begin{tabular}{|lllll|}
\hline FORMA POÉTICA: & $\mathrm{A}\left(1^{\mathrm{a}}\right.$ parte) & $\mathrm{B}$ (refrão central) & $\mathrm{C}$ (segunda parte) & $\mathrm{D}$ (refrão principal) \\
FORMA MUSICAL: & $\mathrm{A}, \mathrm{B}(\ldots)$ & $\mathrm{C}$ & $\mathrm{D}, \mathrm{E}(\ldots)$ & $\mathrm{F}$ \\
\hline
\end{tabular}

Como exemplo da relação flexível que pode ocorrer entre as formas poética e musical, cito o samba Brasil: visões de paraísos e infernos, apresentado pela Unidos do Viradouro no ano de 2000. Sua letra integral é a seguinte:

\section{Brasil: visões de paraísos e infernos}

(Gilberto Gomes, R. Mocotó, Gustavo, P.C. Portugal, Dadinho)

(PRIMEIRA PARTE)

Na era medieval começa o meu carnaval

No paraíso eu me vesti de branco

E no "martírio eterno", o vermelho é meu manto

Navegando ao Oriente, "seu" Cabral

O "Jardim das Delícias" descobriu

"Seu" Caminha escreveu o que ele viu

Maravilhas do Brasil

Bordunas, tacapes e Ajarés

Na dança o índio põe aos seus pés

Mas nascem ideias diversas, são mentes perversas

Não foi essa a lição dos pajés 


\section{(REFRÃO CENTRAL)}

Irê, irê, pra agba yê

O negro canta, o negro dança em liberdade

Irê, irê, pra agba yê

Pra agba yê, felicidade

\section{(SEGUNDA PARTE)}

Bem longe daqui, na festa da coroação

O negro africano, nos seus desenganos

Desfaz-se dos planos, pro branco explorar

Preso nas correntes da vida

São marcas que jamais esquecerá

Mas o tempo passou e a felicidade eu vejo brotar

Na luz da esperança, há paz e alegria

Pro rei do universo abençoar

\section{(REFRÃO PRINCIPAL)}

O dia vai raiar, amor, amor

Com a Viradouro eu vou, eu vou, eu vou

Meu canto de amor se espalha no ar

Quinhentos anos vamos festejar

Já a forma musical é dividida da seguinte maneira (Figuras 39 a 42): 
Figura 39 - Primeira parte de "Brasil: visões de paraísos e infernos", Viradouro, 2000

"Brasil: visões de paraísos e infernos", Viradouro, 2000

(Gilberto Gomes / R. Mocotó / Gustavo / P.C. Portugal / Dadinho)
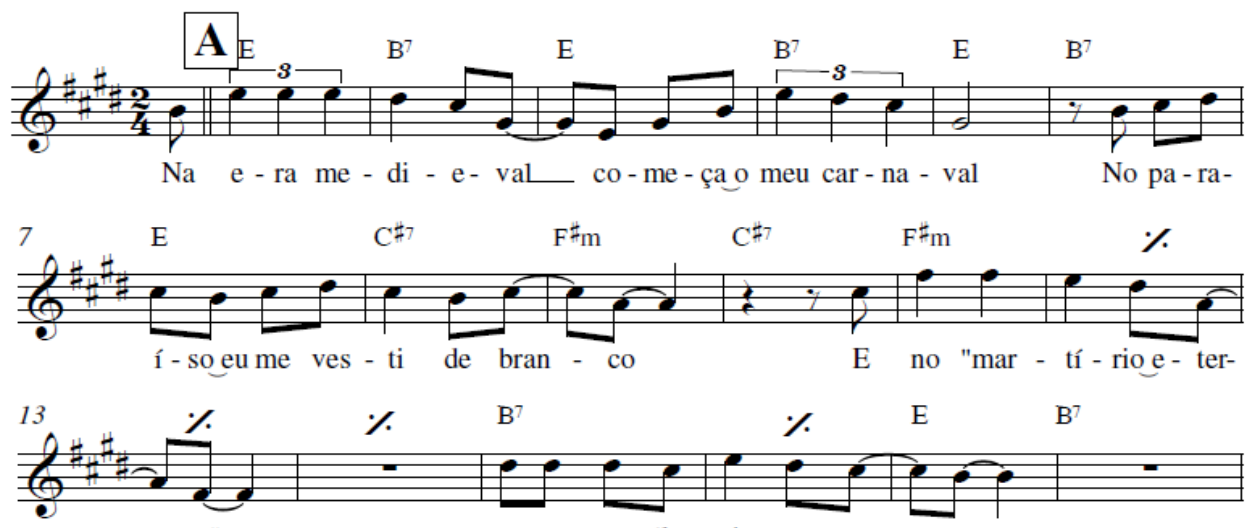

- no",-

o ver-me-lho é meu man - to__
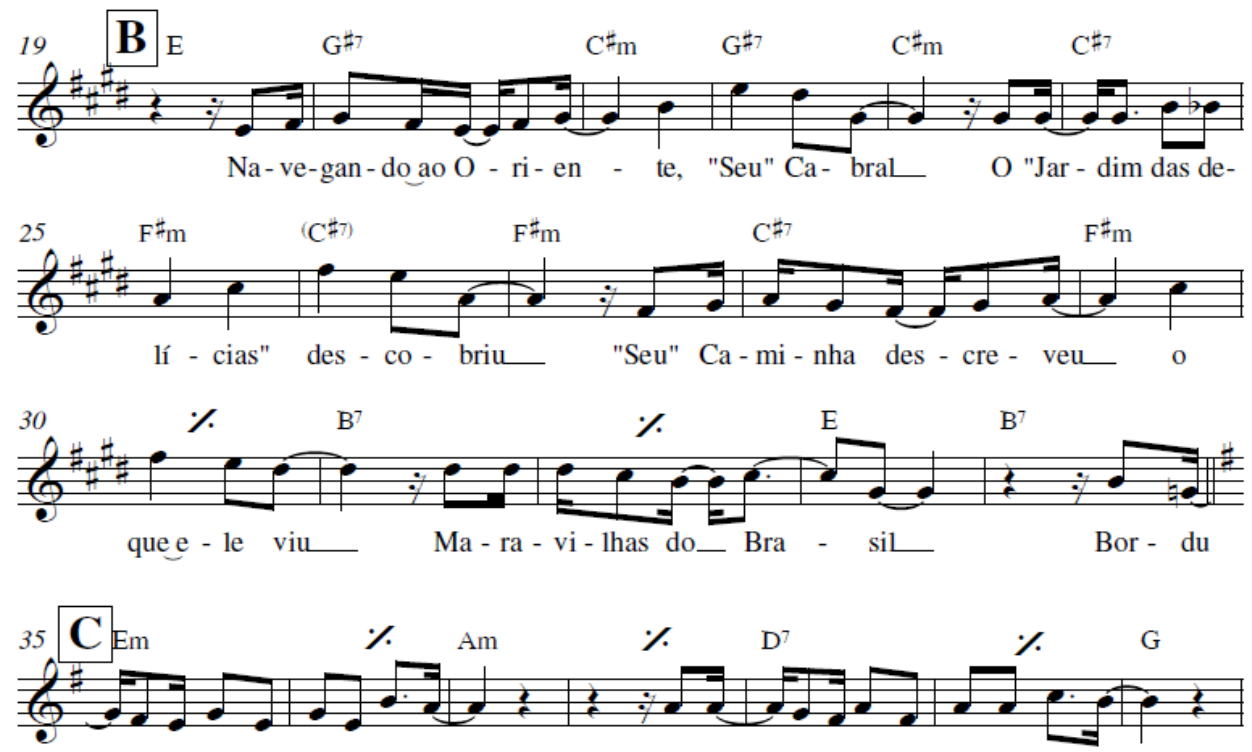

- nas,ta-ca-pes e a-ja-rés_

Na dan - ça o ín-dio põe aosseus pés_
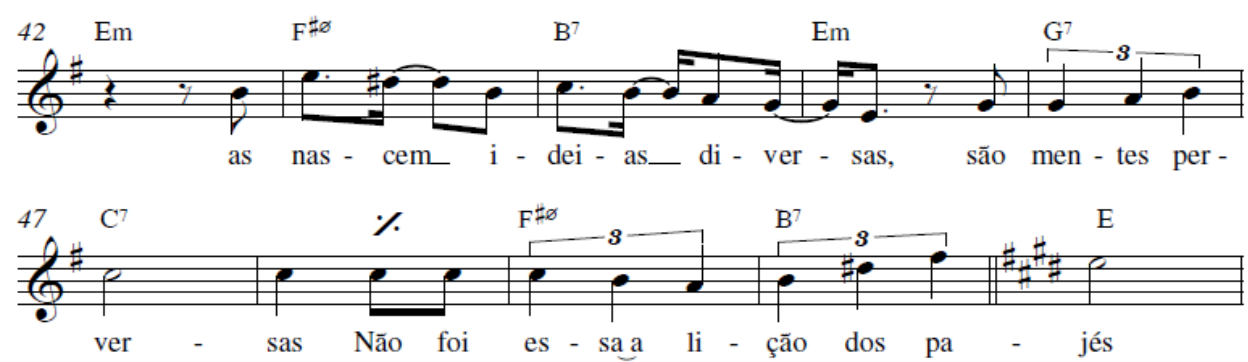
Figura 40 - Refrão central de "Brasil: visões de paraísos e infernos", Viradouro, 2000
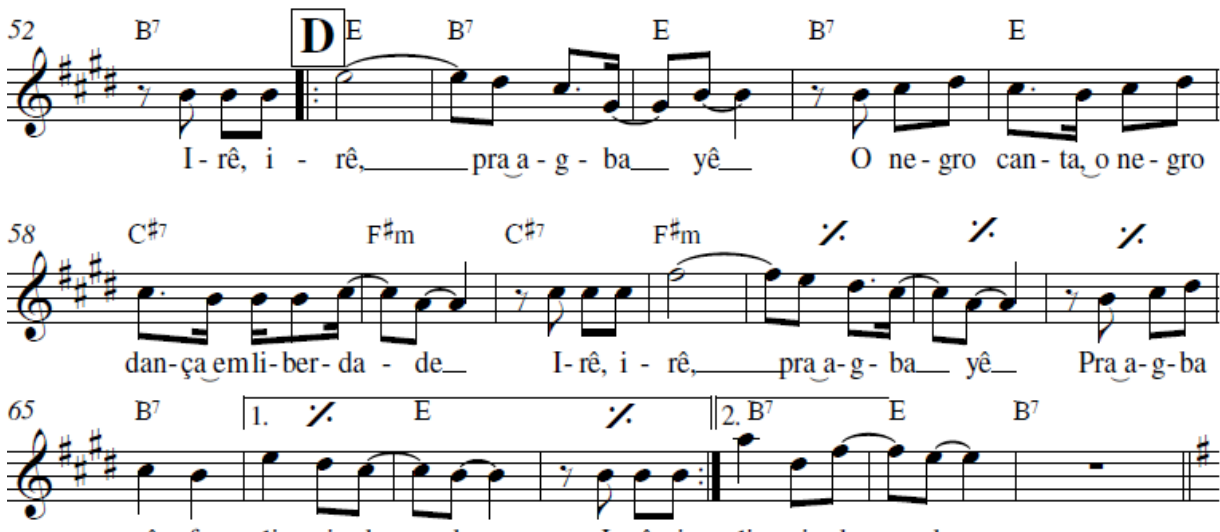

yê, fe - li - ci-da - de I- rê, i - li - ci-da - de_

Figura 41 - Segunda parte de "Brasil: visões de paraísos e infernos", Viradouro, 2000
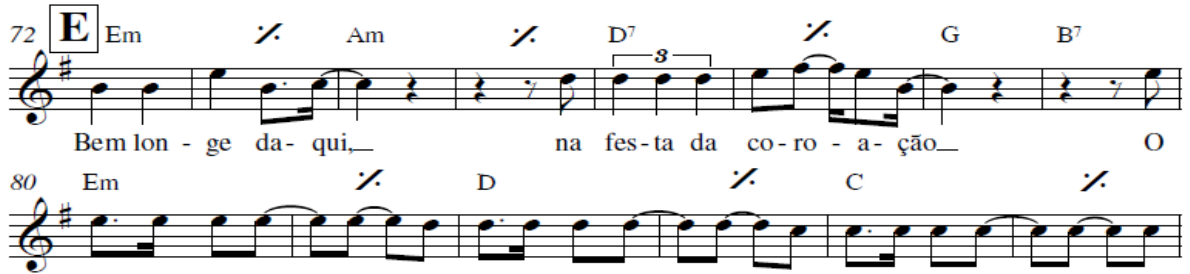

ne -gro a-fri- ca - no,_ nos seus de-sen-ga - nos_Des faz-se dos pla - nos_pro
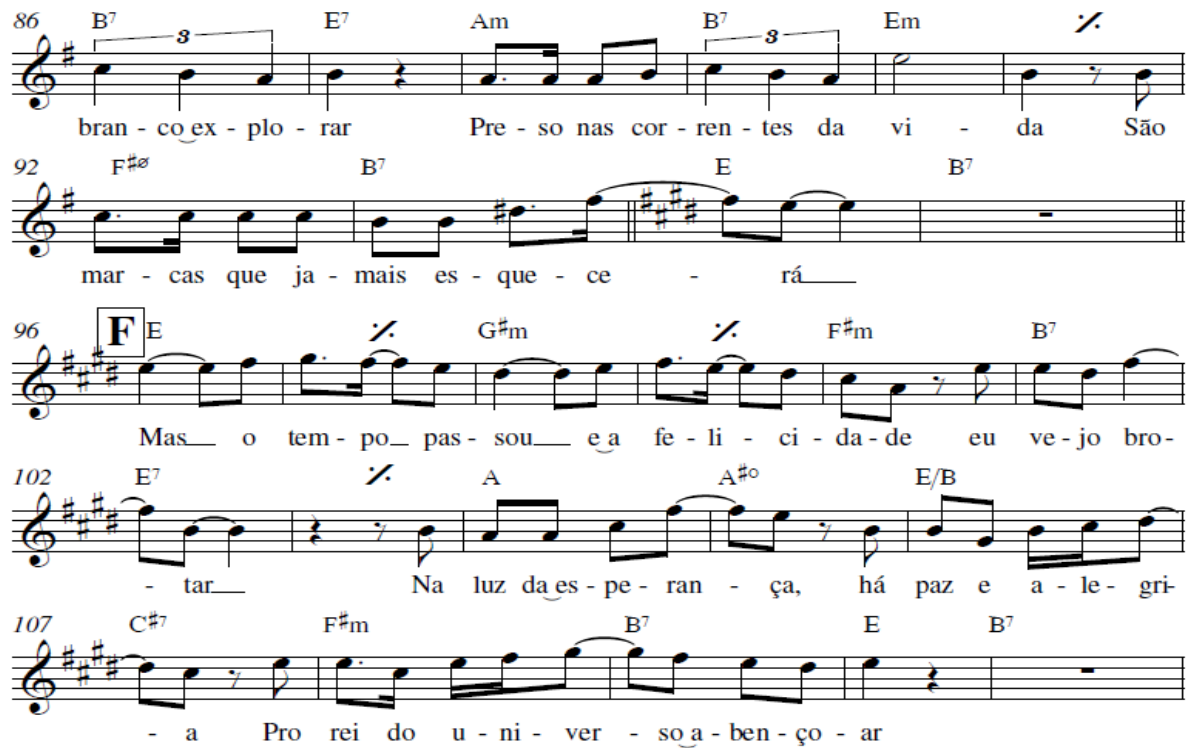
Figura 42 - Refrão principal de "Brasil: visões de paraísos e infernos", Viradouro, 2000

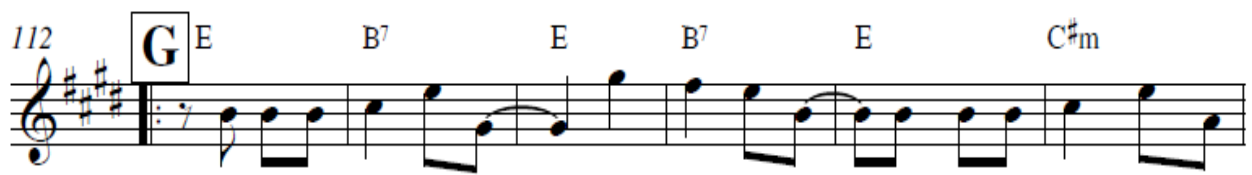

O di - a vai rai-ar,__ a - mor, a- mor_Coma Vi-ra-dou-roe eu vou,
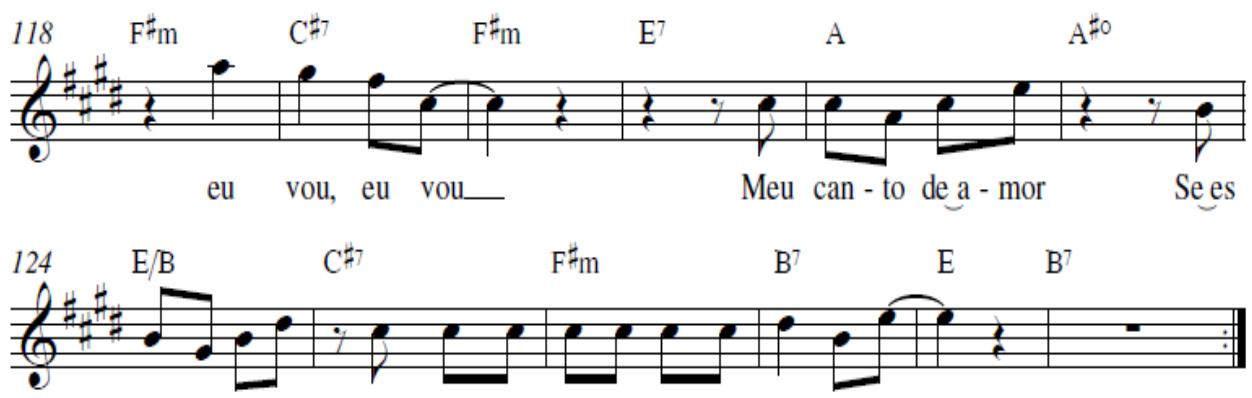

pa-lha no ar Qui-nhen-tos a-nos,va-mos fes-te- jar

Portanto, as formas poética e musical desse samba podem ser assim relacionadas (Figura 43):

Figura 43 - Relação entre as formas poética e musical em "Brasil: visões de paraísos e infernos", Viradouro, 2000

\begin{tabular}{|lllll|}
\hline FORMA POÉTICA: & A $\left(1^{\mathrm{a}}\right.$ parte) & B (refrão central) & C (segunda parte) & D (refrão principal) \\
FORMA MUSICAL: & A, B, C & D & E, F & G \\
\hline
\end{tabular}

De qualquer maneira, a construção do discurso musical do samba-enredo contemporâneo é pré-determinada pela forma poética. $E$ mais: o plano melódico costuma cumprir um comportamento bem definido para cada uma das partes da forma padrão. Por exemplo, o refrão principal ("D" na forma poética), conforme nos disse em entrevista um dos compositores do samba acima citado, Gusttavo Clarão, "normalmente é o auge, é a parte que deve marcar para cair na boca do povo" (Clarão, 2009, entrevista ao pesquisador). Já o refrão central ("B" 
da forma poética) geralmente é menos explosivo que o principal, assumindo em muitos casos um caráter lírico.

Se, de uma maneira geral, a primeira parte tem o papel de introduzir a história a ser contada, fazendo com que a melodia pouco a pouco alcance um primeiro pico de energia (refrão central), a segunda parte atua como um elemento contrastante, através do decaimento dinâmico da bateria e, com frequência, da mudança da melodia para um registro mais grave (Figura 44):

Figura 44 - Início da segunda parte de "O caso do por acaso", Salgueiro, 1995

"O caso do por acaso", Salgueiro, 1995

(Márcio Paiva / Adalto Magalha / Eduardo Dias / Quinho)

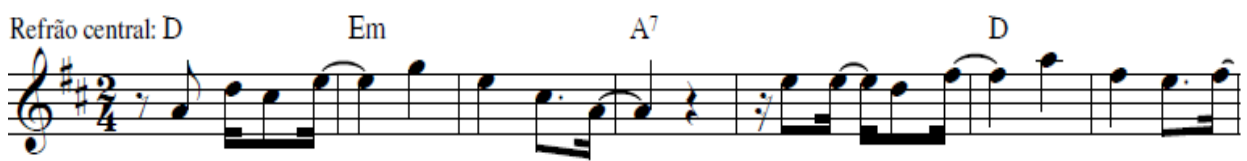

A-mor,a- mor,-quem foi,quem foi__ Que des-co- briu_o meuBra-sil

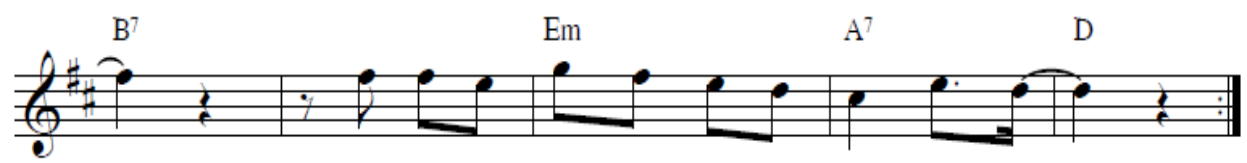

Pois o tra - ta - doeu sei que e - xis- tiu

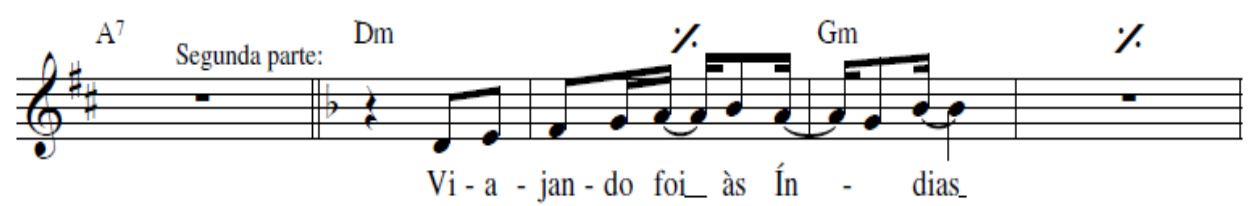

A segunda parte é ainda o momento do samba em que se manifesta um maior lirismo, por meio da utilização de notas de longa duração e uma movimentação harmônica mais dilatada. Conforme explica o compositor e intérprete Diego Nicolau13,

13 Diego Nicolau, 33 anos, é um dos mais requisitados intérpretes de sambaenredo do Rio de Janeiro. É compositor de obras para a Acadêmicos do Cubango (2006, 2008, 2010), Viradouro (2012), Mocidade Independente (2012, 2014), além de escolas de outros estados do Brasil. 
Em quase todas as escolas, a segunda parte do samba é o descanso da bateria. A bateria vem tocando com todos os instrumentos, por exemplo, tamborim, cuíca e chocalho o samba inteiro e quando chega na segunda ela descansa. Então, geralmente a melodia dessa parte tem que ser mais solta, para que o cara do surdo, por exemplo, possa trabalhar descansando. Então, ele vem tocando naquela loucura [do refrão central] e quando vira para a segunda parte ele vai mais tranquilo, bem solto, pra descansar e voltar no refrão [principal], ou na preparação do refrão, e explodir novamente (Nicolau, 2015, entrevista ao pesquisador).

Podemos notar nos sambas abaixo a utilização da mesma sequência harmônica e de um tratamento rítmico-melódico similar, notadamente no que diz respeito a presenças das em cada mudança de acorde (Figura 45 a 47 ):

Figura 45 - Segunda parte de "Cara ou coroa, as duas faces da moeda", Vila Isabel, 1995

"Cara ou coroa, as duas faces da moeda", Vila Isabel, 1995

(Evandro Bocão / André Diniz)

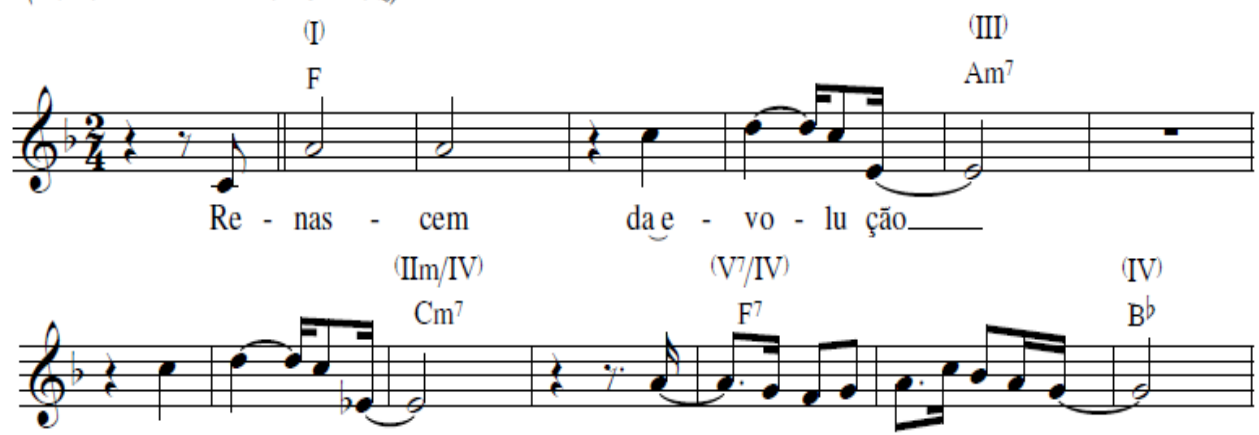

no - vos_ fi- lões_

En - tre oO-ci-den-te re-gi- ões 
Figura 46 - Segunda parte de "Manoa, Manaus, Amazonas, Terra Santa: Alimenta o corpo, equilibra a alma e transmite a paz", Beija-Flor, 2004

"Manoa, Manaus, Amazonas, Terra Santa:

Alimenta o corpo, equilibra a alma e transmite a paz", Beija-Flor, 2004

(Claudio Russo / José Luis / Marquinhos / Jessey Beija-Flor)

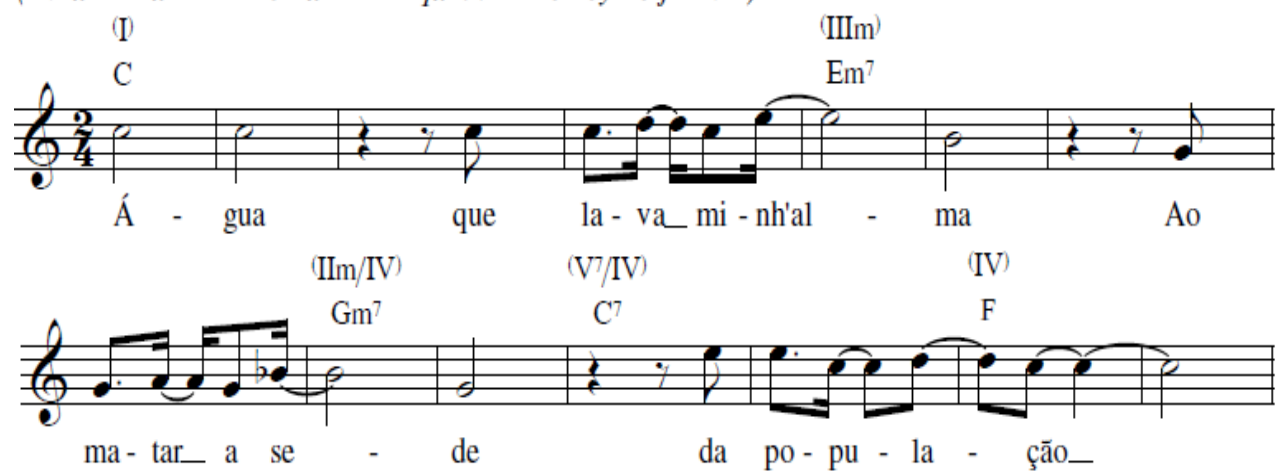

Figura 47 - Segunda parte de "Reconstruindo a Natureza, recriando a vida: o sonho vira realidade”, Portela, 2008

"Reconstruindo a Natureza, recriando a vida: o sonho vira realidade", Portela, 2008 (Júnior Scafura / Diogo Nogueira / Ciraninho / Ari do Cavaco / Celsinho de Andrade)

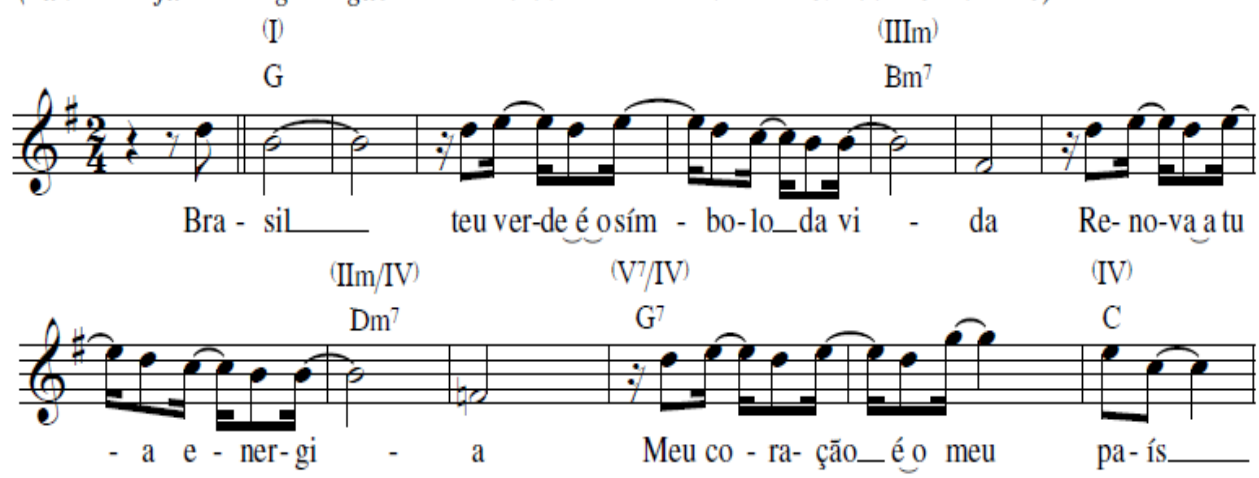

É interessante notar que a forma do samba está intimamente ligada ao comportamento do componente de escola de samba. Um samba com muitos refrões poderia ser exaustivo para quem o canta por muito tempo, como ocorre na situação do desfile; um samba sem refrões, por sua vez, poderia ser enfadonho. Assim, a alternância entre refrões e estrofes parece garantir o equilíbrio ideal entre momentos de 
maior ou menor empolgação. Para Eduardo Medrado, a comunicabilidade com o público também é um fator a ser levado em conta: "o porquê de se ficar refém da forma de dois refrões é que os sambas de hoje querem ter pelo menos dois momentos em que os caras [público presente no desfile] aprendam algo do samba" (Medrado, 2009, entrevista ao pesquisador).

Creio, portanto, que há consenso entre compositores, componentes e instrumentistas que a predominância do padrão formal acima descrito pode ser considerada uma mudança de grandes consequências tanto para o ato de compor um samba-enredo, visto que certos parâmetros discursivos estão estabelecidos a priori, quanto para a dinâmica do desfile de escola de samba, já que estabelece certos parâmetros de comunicabilidade entre escola e público.

\section{Considerações finais}

Podemos dizer, portanto, que alguns dos fenômenos aqui descritos cumprem ao menos duas das condições sugeridas por Blacking, para a identificação de mudanças:

1) "Mudança perceptível nas normas de performance reconhecida como tal pelos intérpretes e o público" (1977: 19), como é o caso do padrão formal;

2) "Uma mudança perceptível nas normas de performance que não é categorizada como tal por intérpretes e público, (...) mas é considerada como significante por um observador externo, principalmente como resultado de uma medição objetiva" (1977: 20), como é o caso da marchaenredo, em que há divergências entre os compositores sobre as consequências para a composição e performance, mas há um consenso entre os pesquisadores de que houve mudanças estruturais no samba-enredo; 
Os parâmetros estabelecidos por Blacking se mostram, assim, de grande utilidade para o estudo do samba-enredo e, provavelmente, de outros gêneros musicais populares.

Como mencionei, não podemos negar que o samba-enredo possui uma tendência de repetição de certas estruturas inerente à sua condição de gênero de música popular. Por outro lado, a recorrência de certos padrões pode, sim, estar ligada ao uso intencional de clichês melódicos e poéticos pelos compositores de forma a obter uma maior capacidade de comunicação com o público, o que estaria em conformidade com a definição de música popular defendida por Adorno; ao surgimento dos chamados "escritórios de sambas", grupos de compositores que escrevem de maneira padronizada para diversas escolas e dispõem de recursos financeiros suficientes para arcar com altos gastos das disputas internas de samba-enredo; ou à resistência das diretorias das escolas em escolher sambas-enredo contrários ao modelo vigente, temerosas de que estes possam ser punidos pelos jurados do desfile.

Ainda que o processo de padronização ocorrido nas últimas três décadas tenha colocado a capacidade de renovação do samba-enredo em perigo, tenho identificado recentemente uma preocupação de muitos compositores com a criação de obras de maior singularidade melódica e formal14. É possível que o surgimento de sites especializados em carnaval15, que disponibilizam os sambas concorrentes das disputas internas de cada escola de samba para audição e julgamento estético de milhares de aficionados pelo gênero, tenha estabelecido um novo grau de exigência para os compositores, já que uma obra bem recebida e com

14 Destaco, entre outras, a parceria de Toninho Nascimento e Luiz Carlos Máximo, que fez uso de três refrões nos seus sambas recentes para a Portela (2012, 2013, 2014), quebrando o padrão formal descrito neste artigo; e a parceria de Eduardo Medrado e Kleber Rodrigues, que há mais de quinze anos tem desenvolvido um projeto estético mais radical, no qual se destacam a complexidade harmônica e a irregularidade na construção das linhas melódicas.

15 Carnavalesco (www.carnavalesco.com.br), $\quad$ SRZD (www.sidneyrezende.com/editoria/carnaval), entre outros. 
um grande número de audições pode ser considerada uma forte candidata para ir à avenida. De qualquer forma, ainda é cedo para sabermos se essa nova forma de apreciação do repertório influenciará ou mesmo já influencia a dinâmica do carnaval, mas é certo que o pesquisador tem hoje em dia uma ideia muito maior das diversas maneiras de compor samba-enredo do que somente a audição das obras gravadas nos discos oficiais poderia levá-lo a crer.

\section{Referências}

ADORNO, Theodor. Sobre música popular. In: COHN, Gabriel (Org.). Coleção Grandes Cientistas Sociais - Adorno. São Paulo: Ática, 1986.

AUGRAS, Monique. O Brasil do samba-enredo. Rio de Janeiro: Fundação Getúlio Vargas, 1998.

BLACKING, John. Some Problems of Theory and Method in the Study of Musical Change. Yearbook of the International Folk Music Council, Vol. 9, pp. 1-26, 1977.

CABRAL, Sérgio. As escolas de samba do Rio de Janeiro. Rio de Janeiro: Lumiar, 1996.

COELHO, Márcio. Frevo-enredo: de como o samba-enredo tende a se tornar marchinha de carnaval. Estudos semióticos, São Paulo, v.5, n.1, 2009. Disponível em: $\quad<\quad$ http://www.fflch.usp.br/dl/semiotica/es/eSSe51/2009esse51mlgcoelho.pdf $>$. Acesso em 19 de novembro de 2011.

GOLDWASSER, Maria Julia. O palácio do samba: estudo antropológico da Escola de Samba Estação Primeira de Mangueira. Rio de Janeiro: Zahar, 1975.

IKEDA, Alberto. Escolas de samba ou de marcha?. O Estado de São Paulo, São Paulo, 24 de fevereiro de 1990. Suplemento Cultura, p. 3-4.

LIESA. Manual do Julgador - Carnaval 2015. Disponível em: < liesa.globo.com/2015/por/03-

carnaval/manual/ManualdoJulgadorCarnaval2015.pdf $>$, Acesso em 09 de agosto de 2015.

RODRIGUES, Ana Maria. Samba negro, espoliação branca. São Paulo: Editora Hucitec, 1984. 
SANDRONI, Carlos. Feitiço decente: transformações do samba no Rio de Janeiro (1917-1933). Rio de Janeiro: Jorge Zahar; Ed. UFRJ, 2001.

TATIT, Luiz. Marchinha e samba-enredo. Folha de São Paulo, São Paulo, 6 mar. 2000. Caderno Opinião, Tendências/Debates, p. 3.

VIZEU, Carla Maria de Oliveira. O samba-enredo carioca e suas transformações nas décadas de 70 e 80: uma análise musical. Dissertação (mestrado) Universidade Estadual de Campinas, Instituto de Artes, Campinas, 2004.

\section{Entrevistas}

CLARÃO, Gusttavo. Entrevista ao pesquisador. Perguntas enviadas e respondidas por e-mail. Entrevista concedida no dia 06 de fevereiro de 2009.

MEDRADO, Eduardo. Entrevista ao pesquisador. Gravação de áudio. Entrevista concedida no dia 20 de fevereiro de 2009, Rio de Janeiro.

NICOLAU, Diego. Entrevista ao pesquisador. Gravação de vídeo. Entrevista concedida no dia 01 de abril de 2015, Rio de Janeiro. 
196 Yuri Prado

Padrões musicais do samba-enredo na era do Sambódromo 